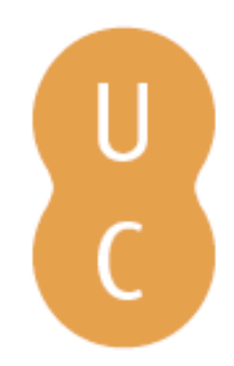

\title{
nombalina
}

\section{Irreligiosidad y literatura en Atenas: actualización científica}

Autor(es): $\quad$ Ramón Palerm, V. M.

Publicado por: Imprensa da Universidade de Coimbra

URL

persistente: URI:http://hdl.handle.net/10316.2/44018

DOI: $\quad$ DOl:https://doi.org/10.14195/978-989-26-1598-1_3

Accessed : $\quad$ 26-Apr-2023 09:47:26

A navegação consulta e descarregamento dos títulos inseridos nas Bibliotecas Digitais UC Digitalis, UC Pombalina e UC Impactum, pressupõem a aceitação plena e sem reservas dos Termos e Condições de Uso destas Bibliotecas Digitais, disponíveis em https://digitalis.uc.pt/pt-pt/termos.

Conforme exposto nos referidos Termos e Condições de Uso, o descarregamento de títulos de acesso restrito requer uma licença válida de autorização devendo o utilizador aceder ao(s) documento(s) a partir de um endereço de IP da instituição detentora da supramencionada licença.

Ao utilizador é apenas permitido o descarregamento para uso pessoal, pelo que o emprego do(s) título(s) descarregado(s) para outro fim, designadamente comercial, carece de autorização do respetivo autor ou editor da obra.

Na medida em que todas as obras da UC Digitalis se encontram protegidas pelo Código do Direito de Autor e Direitos Conexos e demais legislação aplicável, toda a cópia, parcial ou total, deste documento, nos casos em que é legalmente admitida, deverá conter ou fazer-se acompanhar por este aviso.

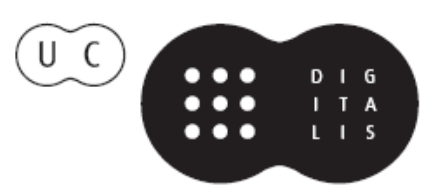




\section{Irreligiosidad y}

Literatura en la Atenas Clásica

V.M. Ramón Palerm, G. Sopeña Genzor, A.C. Vicente Sánchez (eds.)

IMPRENSA DA UNIVERSIDADE DE COIMBRA 


\section{IRRELIGIOSIDAD Y Literatura en Atenas: Actualización Científica}

\section{(IRRELIGIOSITY AND LiterATURE IN Athens: Scientific Update)}

V.M. Ramón PALERm (Orcid ID: 0000-0001-5566-5753; vmramon@unizar.es) Universidad de Zaragoza 
(Página deixada propositadamente em branco) 
El análisis de la irreligiosidad antigua no es tarea fácil: la crítica especializada se ha enfrentado al tema con incertidumbres, fluctuaciones, perplejidades. Efectivamente, la orientación metodológica de los modelos exegéticos y la complejidad intrínseca de la cuestión son factores tamaños en la explicación del fenómeno; y el estudioso siente la tentación de remedar al gran Protágoras en su celebrado axioma sobre el conocimiento de los dioses (DK 80 B 4): hay muchos impedimentos, la oscuridad del problema y la brevedad de nuestra vida.

Así las cosas, el lector puede lícitamente interrogarse por el sentido del título que precede a nuestra exposición. Una respuesta a esta eventual pregunta remite de manera inmediata a la obra del investigador más sobresaliente en los últimos decenios sobre el problema de la irreligiosidad y del ateísmo antiguos: el clasicista polaco Marek Winiarczyk ${ }^{2}$. Sucede que, a lo largo de una dilatada y fecunda producción, Winiarczyk ha asentado las bases metodológicas para acometer trabajos sistemáticos desde una perspectiva que aborde la factura de estudios críticos sobre la irreligiosidad ${ }^{3}$, la atención debida al léxico de pertinencia que revelan los respectivos autores ${ }^{4}$, la cautela conceptual en la verificación del ateísmo antiguo 5 . El caso es que sus aportaciones, de enorme talla históricofilológica, marcan un punto de inflexión y posibilitan el enfoque renovado de exégesis. Por ello, y merced a su pericia singular, Winiarczyk proporciona una clasificación exhaustiva de la bibliografía que, a propósito del ateísmo y de la irreligiosidad, se ha publicado hasta el año $1990^{6}$. Esta circunstancia justifica una actualización comentada de las contribuciones relevantes, editadas en los últimos años, sobre la cuestión.

A decir verdad (y siendo respetuosos con la diacronía de los hechos) la semilla para que fructificara el 'método-Winiarczyk' estaba plantada. En efecto, la escuela de sello primordialmente germano había conformado un modelo explicativo que analizaba el ateísmo desde los postulados inherentes a un pensamiento antiguo, condicionado este por el platonismo doctrinal y por el cristianismo triunfante. Pese a los esfuerzos pioneros de Drachmann, Fahr y más tarde Guthrie ${ }^{7}$, como autores de renombre, primaron los criterios de naturaleza omnicomprensiva sobre la religión, la moral y la conciencia religiosa que fomentaron Wilamowitz y sus epígonos hasta llegar a la figura mayúscula de Nestle, el cual vino a corroborar el

\footnotetext{
2 Bernabé 2008: 623.

${ }^{3}$ Winiarczyk 1990: 14.

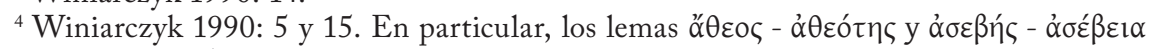
(entre otros de nota) merecen la reflexión concienzuda de Winiarczyk.

${ }^{5}$ Winiarczyk 1981: XIII.

${ }^{6}$ Winiarczyk 1994. No obstante, la compilación de Winiarczyk, exhaustiva como queda dicho, adolece de comentarios mínimamente críticos sobre las publicaciones oportunas.

${ }^{7}$ Drachmann 1922; Fahr 1969; Guthrie 1971. La valoración del proceso dialéctico, que glosamos en estas primeras reflexiones, se corresponde con una exposición revisada de Ramón Palerm 2014a.
} 
estudio de las ideas religiosas en perjuicio de los factores, autores y obras de signo diverso ${ }^{8}$. El idealismo imperante favoreció cierto usus interpretativo en relación con los autores y géneros, escrutados desde una orientación segmentada y uniforme. Por lo demás, los autores oficialmente ateos, según se reiteraba mediante inercia crítica, venían a corresponderse con el canon que los catálogos postclásicos habían sancionado sobre la base del inventario que propuso Clitómaco de Cartago, un autor neoacadémico del siglo II a.C`: los nombres de Diágoras, Protágoras, Pródico, Critias (junto a otros destacables, sucesivamente incorporados), constaban en los censos más reputados de antiguos y modernos, al extremo de tipificar una clasificación basada en criterios apriorísticos ${ }^{10}$.

Lo cierto es que, con ese vademécum doctrinal del pasado, Winiarczyk promovió las indagaciones sobre el problema desde una óptica medida, ajena a sesgos de tendenciosidad dogmática. De esta guisa, creemos que el revival experimentado por los estudios acerca de la irreligiosidad antigua debe muchodirecta o indirectamente- a la impronta del filólogo polaco. Sin ir más lejos, esta circunstancia explica en buena medida la edición del The Cambridge Companion to Atheism. Y ahí está, verbigracia, el Congreso desarrollado en el Corpus Christi College de Oxford con arreglo al tema Disbelief in Antiquity: an Interdisciplinary Conference. Asimismo, son destacables las recientes aportaciones de Sorel, que acoge descriptivamente aspectos de terminología religiosa e irreligiosa en el mundo griego, de Peels, quien postula un análisis léxico-semántico, contrastado,

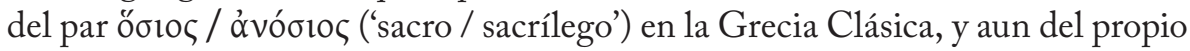
Winiarczyk, el cual ha acometido un estudio pormenorizado sobre la figura de Diágoras de Melos con indicaciones sugestivas sobre los posibles orígenes del ateísmo en Grecia (aquí entendido en su acepción radicalmente moderna) ${ }^{11}$.

Con todo, procede señalar que la atención metodológica a las propuestas de Winiarczyk ha sido explotada solo incidentalmente, ya que la orientación exegética del panorama actual no es ajena a un sello doctrinal (en gradación desigual, justo es decirlo) y oscila entre posiciones distinguidas: discretamente conservadoras a veces; ponderadamente críticas en ocasiones; resueltamente subversivas con frecuencia. De manera general y representativa, sirvan algunos ejemplos ilustrativos.

${ }^{8}$ Cf. Nestle 1950, donde el filólogo alemán realiza una síntesis, sobre la categoría del ateísmo en la Antigüedad, inherente a la tendencia metodológica y doctrinal de la época.

${ }^{9}$ Winiarczyk 1976.

${ }^{10}$ Sobre los catálogos tipificados de ateos, cf. Winiarczyk 1984, en particular 157-158 y 182 n. 10; Grau 2010a: 468 y n. 103; Grau 2010b, especialmente 59 y n. 10.

${ }^{11} \mathrm{El}$ mencionado Companion acoge un capítulo relativo al ateísmo en la Antigüedad y, de hecho, ha sido ya traducido en español (Martin 2010). Por otra parte, las Jornadas del Congreso citado (junio de 2013) han propiciado el volumen de Whitmarsh 2015. Por lo demás, las publicaciones respectivas de Sorel y de Peels han aparecido en 2015. En última instancia, la contribución de Winiarczyk es recentísima (2016). 
En la primera de las posiciones contamos con un reciente y notable ensayo que, entre nosotros, la profesora Durán López ha consagrado a la percepción que los sofistas manifiestan sobre la crisis religiosa del siglo $V$ a.C. y a la relación de estos autores con la divinidad y con el fenómeno religioso ${ }^{12}$. El resultado de esta monografía-sólidamente pormenorizada-se resuelve en una tesis de factura conservadora que muestra a Critias, en la práctica, como el único sofista de señaladas tendencias irreligiosas por razones probablemente de índole política ${ }^{13}$.

En la segunda de las adscripciones es destacable el cometido del historiador de las religiones holandés, Jan Bremmer, quien efectúa un examen de textos relevantes, presumiblemente críticos sobre la religión y las deidades antiguas. Bremmer incide en la importancia de la literaturización, inherente a la Atenas del siglo $\mathrm{V}$ a.C., para fundamentar el auge de la conciencia crítica sobre las tradiciones religiosas ${ }^{14}$. Asimismo, y en el marco del creciente interés por el fenómeno irreligioso en la Antigüedad Clásica, el propio Bremmer ha consignado un capítulo de conjunto sobre el ateísmo en la Antigüedad en la edición del The Cambridge Companion to Atheism ${ }^{15}$. En esta ocasión, la sinopsis de Bremmer resulta de lectura atractiva en un tono de inteligente divulgación.

El tercero de los enfoques críticos resulta, a nuestro entender, menos afortunado; y ello al margen de la adhesión ocasional que ciertos puntos de vista puedan concitar. Ocurre que en el final del siglo pasado y en los inicios del presente hemos asistido a perspectivas de análisis disyuntivas de las tradicionalmente heredadas. En ciertos trabajos de inclinación ostensiblemente polemista y aun excéntrica, el pensador francés Michel Onfray viene cimentando la arquitectura de un pensamiento corrosivo, subversivo de la filosofía idealista ${ }^{16}$. Las teorías de Onfray abogan por la propuesta de soluciones ajenas a la cultura academicista, de impronta germana, y modelan una contrahistoria de la filosofía que menoscabe los fundamentos del pensamiento idealista vigente en la historia escolástica de la tradición cultural del siglo XX. En una dirección hondamente rupturista se halla también el modelo explicativo de Tamagnone ${ }^{17}$, quien (simplificadora

12 Durán López 2011.

${ }^{13}$ Durán López 2011: 425. La autora interpreta la solución ateísta de Critias como un caso de instrumentalización política de signo contrario al llamado 'Decreto de Diopites'.

${ }^{14}$ Bremmer 1982: 48-52. En un tono sugestivamente provocativo, Bremmer se cuestiona (acaso prescindiendo del componente esencialmente ritual de la religión griega) que, con el rechazo de los mitos y con el escepticismo hacia los dioses, la religión griega no feneciera de muerte natural.

${ }^{15}$ Bremmer 2010. En todo caso, el autor expone estrictamente los puntos elementales del tema con una parquedad incisiva en los problemas fundamentales.

${ }^{16}$ Onfray 2007 (aquí consultado mediante la traducción española del original francés impreso en 2006). Véanse algunos argumentos críticos sobre la virtualidad metodológica del 'modelo-Onfray' en Ramón Palerm 2009a y 2009b.

17 Tamagnone 2005. Debe considerarse atentamente la reseña hipercrítica de Warren 2007. 
e inadecuadamente) asocia el materialismo antiguo con el ateísmo e identifica el idealismo con el teísmo. Por su parte, Zeppi defiende una línea asimismo debeladora y fundamenta los orígenes del ateísmo antiguo en el debate intelectual propio de la Atenas Clásica ${ }^{18}$. Con argumentos de mayor fuste que Onfray o Tamagnone,Zeppi glosa brillantemente la antinomia 'religiosidad / irreligiosidad' de la época pero, a nuestro parecer, emite juicios sobremanera esquemáticos acerca del carácter religioso o irreligioso que presentarían los autores pertinentes. En este caso, como sucede con Onfray y con Tamagnone, el autor da pábulo a ciertos pasajes en perjuicio de otros proclives a una interpretación alternativa y, a la postre, justifica el modelo explicativo sin revisar la totalidad de los pasajes que permitieran consolidar la fuerza probatoria de su tesis.

En resolución: si la filología alemana de cuño idealista favoreció una imagen parcial de textos canonizados, enfocados a una tipología de paideía muy difundida en la tradición occidental, otros modelos amparados en criterios doctrinales son controvertibles; y aun resueltamente insatisfactorios si filtran por el tamiz de su sistema ideológico la realidad textual de los autores que traen a colación; si, en otras palabras, privilegian determinados pasajes que parecen aproximarse a sus teorías y desprecian aquellos que dan la impresión de contravenirlas. Por todo ello, pensamos que un análisis ponderado sobre el tema aconseja profundizar en la línea trazada por Winiarczyk y centrar las expectativas en una metodología que acometa la realidad textual mediante una interpretación de los autores significativos ajena a posiciones sesgadas o prejuicios ideológicos ${ }^{19}$.

\section{Actualización científica (1991-2016)}

Así las cosas, expuestos de manera sinóptica los planteamientos doctrinales más acreditados, cabe centrarnos en las aportaciones críticas de relieve concernientes a los géneros y a los autores oportunos. Como anticipábamos en este sentido, nos atendremos selectivamente a publicaciones de mérito que la comunidad científica ha facilitado con posterioridad al inventario bibliográfico de Winiarczyk ${ }^{20}$. Al respecto, debemos establecer una puntualización. Obviamente la sofística no constituye en sentido estricto un género literario, acorde a una tipología común: efectivamente, se trata de un movimiento intelectual, de

${ }^{18}$ Zeppi 2011. Para ser exactos, Zeppi publicó sus artículos periódicamente durante los años 1988-1989, artículos que Sylvain Gullo recopila en la versión francesa de 2011.

19 Esta orientación que saludamos, de naturaleza inductiva, preside verbigracia los estudios del profesor Calderón Dorda aplicados al vocabulario religioso de la literatura griega. Cf. Calderón Dorda 2013; 2014; 2015a; 2016a; 2016b. Por lo demás, resulta evidente que, en el ámbito de la irreligiosidad griega, carecemos de un estudio parangonable al magnífico que consagró Burkert sobre el tema de la religión griega (publicado originalmente en 1977 y cuidadosamente traducido al español en 2007).

${ }^{20}$ Winiarczyk 1994. 
maneras distinguidas, cuya plasmación literaria conocemos básicamente en modo fragmentario e indirecto; por ello, al compás de lo advertido en el Prefacio de este volumen, hemos decidido soslayar la inclusión de pasajes que, por lo demás, disponen de un examen ya concienzudo en la tradición histórico-filológica. Con todo, habida cuenta la importancia de la sofística en la génesis y en el desarrollo de los géneros literarios aquí pertinentes, juzgamos procedente iniciar este apartado mediante la actualización comentada del movimiento sofístico y de los autores más representativos con arreglo a nuestro ámbito de estudio.

Continuando líneas de investigación precedentes ${ }^{21}$, los estudios recientes insisten en un factor incontrovertible: los sofistas constituyen ese movimiento que hunde sus raíces en las posiciones intelectuales de repulsa a los esquemas míticos, acrisolados por la tradición. En efecto, la crítica de los estudiosos fisicistas a la teología convencional caló honda en la respuesta que, desde postulados antropocéntricos, los sofistas ofrecieron ante el fenómeno religioso. Con todo, la atención al mencionado factor se viene resolviendo mediante ensayos en los que priman, respectivamente, ciertos análisis dispares en su enfoque: la aproximación desde un sesgo radicalmente ateísta; la defensa de la conciencia religiosa en el esquema general de los sofistas; la vinculación del pensamiento sofístico a los acontecimientos políticos del siglo $\mathrm{V}$.

Zeppi, Tamagnone y Onfray (en orden cronológico ahora) son los principales adalides de una orientación rupturista ${ }^{22}$. Para no reiterar aspectos antedichos, nos atendremos a los puntos de estricta incidencia. De entrada, Zeppi brinda un capítulo provocativo sobre la actitud religiosa de los sofistas ${ }^{23}$. A través de una gradación que presenta matices oscilantes, Zeppi sostiene el antiprovidencialismo de Trasímaco (impregnado de pesimismo antropológico ante la desconsideración de los dioses por los asuntos humanos), comenta el agnosticismo de Protágoras, defiende el ateísmo de Pródico y de Critias quienes reconocen, empero, la utilidad práctica de la religión. Asimismo, Tamagnone ofrece un estudio de ambición metodológica que pretende ilustrar el tránsito del ateísmo filosófico en la Antigüedad. A decir verdad, Tamagnone concede a los sofistas una importancia ponderada en ese trayecto ideológico y ubica el movimiento sofístico en los albores secundarios de lo que señala como prodromi del ateísmo griego ${ }^{24}$. Ello le conduce a valorar con particular

${ }^{21}$ Melero 1996: 7-67 ofrece una summa espléndida sobre las aportaciones de la comunidad científica al movimiento de la sofística. Con especial interés para nuestro tema, cf. 41-47. Es asimismo útil la panorámica que presenta Durán López 2011: 31-51.

${ }_{22}$ Pese a estar presentes en el repertorio de Winiarczyk (1994), incidimos excepcionalmente en los artículos de Zeppi dada su compilación posterior en formato de libro y la importancia del mismo (descuidada por lo general entre la crítica).

${ }^{23}$ Zeppi 2011: 83-123.

${ }^{24}$ Tamagnone 2005: 130-139. El autor antepone la importancia que ejercen el naturalismo milesio, el pluralismo ontológico de Empédocles y la fuerza intelectiva de la materia anaxagorea en el devenir del atomismo doctrinal y, por ende, del ateísmo filosófico aquí propugnado (cf. 91-129). 
medida la impronta del agnosticismo inherente a Protágoras, del nihilismo gorgiano y del relativismo ético que exhiben los sofistas. En última instancia, Onfray define indirectamente el movimiento sofístico por oposición al platonismo triunfante en la filosofía occidental ${ }^{25}$. El caso es que, mediante una declaración programática de solemnidad, Onfray fustiga la denominación misma de presocráticos para cuantos precedieron al Sócrates-platonizado. He aquí una censura justificable considerando la inconveniencia de un calificativo que engloba a pensadores de importancia, los cuales se juzgarían precursores fallidos del 'verdadero' conocimiento que capitaliza Platón. Por añadidura, ciertos autores tildados de presocráticos (como Demócrito) sobreviven en el tiempo al propio Sócrates. Finalmente, Onfray acentúa la hostilidad ideológica de Platón contra los sofistas para explicar el descrédito y rehabilitar el papel de estos en la historia de las ideas.

Con todo, las reflexiones religiosas de los sofistas han merecido modelos antagónicos de exégesis que, inversamente al glosado, presentan una cura philologica con elegancia discursiva. Así, destaca la sólida aportación de M.Á. Durán, quien ha firmado un ensayo con lujo de pormenores acerca del problema ${ }^{26}$. En síntesis, la autora reclama una apología vindicativa para el movimiento sofístico desde una óptica conservadora. Admitiendo la preocupación de los pensadores en su conjunto por el análisis del fenómeno religioso desde la percepción estrictamente humana, Durán López persigue cohonestar la valoración racionalmente crítica de los sofistas sobre la religiosidad y la pulcritud con que ahondan en la dimensión espiritual del ser humano. En la práctica, ello conlleva una inquietud de 'religiosidad laica' (permítasenos expresarlo de este modo) para el universo de los pensadores. La propuesta que defiende Durán López resulta atractiva y sostenible sobre rigurosas bases de exégesis, pero no se muestra ajena a la controversia: es notable la dificultad que entraña una resolución metodológica similar en casos dudosamente parangonables; y en nuestra opinión la religión ilustrada que unificaría las distintas posiciones críticas se antoja una inferencia excesiva ${ }^{27}$.

En cualquier circunstancia, debe señalarse que la atención prestada a la óptica religiosa de los sofistas, siquiera indirecta, ha propiciado vías de estudio suplementarias de las comentadas. Se trata de modelos que enlazan la inquietud de la sofística sobre temas religiosos y el devenir de la actividad política en la Atenas finisecular. Particularmente sugestivas son las notas de Giannantoni,

${ }^{25}$ Onfray 2007: 15-21, 53-57 y 89-91.

${ }^{26}$ Durán López 2011. Sobre el andamiaje argumentativo de la autora, son especialmente notables 31-51 y 403-425.

${ }^{27}$ Cf. Melero en el prefacio al libro de Durán López 2011: 27-28. Al cabo, como bien indica Melero, nos hallamos ante un "libro de tesis" $(16 ; 29)$. Por otro lado, la expresión 'religiosidad laica', por nosotros adoptada, resultaría parcialmente equivalente a la designación 'religión filosófica' que menciona Burkert (2007: 405). 
el cual conecta el desprestigio de la religión convencional a la propia acción de los sofistas y al desarrollo de los acontecimientos políticos ${ }^{28}$ : en efecto, la peste de Atenas y el desastre de la flota en Sicilia (comandada por el muy crédulo y supersticioso Nicias) habrían redundado en la ineficacia de las formas religiosas al uso con el resultado finalmente consabido para el imperio ateniense. Esta línea hermenéutica es la que persigue en buena medida Wallace, quien enfatiza los aspectos políticos de incidencia ${ }^{29}$. El investigador penetra en la génesis del movimiento sofístico y traza fronteras generacionales: los sofistas cuya akmé brilla entre 450-430 y los sofistas posteriores al año 430. Con precisiones conceptuales de interés, el autor insiste en que la noción de sofista es irreductible a una clasificación unívoca; y en que la vocación crítica de la religión trascendental resulta divisa común para estos intelectuales que, con un método técnicoempírico, profesaron ante las clases más elevadas (próximas a las posiciones democráticas en época de Pericles, contrarias en época posterior). En el esquema de Wallace, la guerra y la peste de Atenas condujeron a una disociación entre los dirigentes de signo democrático y las capas altas de tendencia crecientemente oligárquica, circunstancia que tiene su reflejo en la involución del 411 cuyo promotor ideológico fue el orador-sofista Antifonte de Ramnunte. Por cierto que el bosquejo de Wallace reduce, acaso en demasía, el complejo proceso ideológico que presenta la evolución de los hechos políticos en la Atenas del siglo V. En todo caso, tiene el mérito de presentar el debate crítico-religioso de los sofistas como factor unificador, sin mengua de las respectivas orientaciones políticas.

Esbozados estos planteamientos, nos detendremos en ciertas contribuciones que singularizan la actitud crítico-religiosa de sofistas reputados.

\section{Protágoras}

Como era de esperar, el escepticismo relativista de Protágoras ha concitado la atención renovada en los estudios de solvencia histórico-filológica. Los celebérrimos fragmentos DK 80 B 1 y B 4, con las propuestas consabidas del homo mensura y del agnosticismo empírico, siguen mereciendo los análisis de rigor pertinentes. Es mérito de Thivel haber subrayado la distinción, troncal en Protágoras, entre los elementos visibles e invisibles, una división de factura heraclitea ${ }^{30}$. Asumiendo este criterio basado en la dialéctica de los contrarios y considerando que los dioses son invisibles, tan legítimo se antojaría defender su existencia como su inexistencia,

${ }^{28}$ Giannantoni 1996: 52-53. Este proceso explicaría el antiprovidencialismo incipiente de unos dioses ajenos a las tribulaciones humanas, factor que habría influido a las reflexiones críticas de Epicuro (53). Por otra parte, el siglo $V$ allana el camino para enjuiciar la correspondencia entre la teología tradicional y los postulados de la política dominante (cf. Osborne 2009: 118-122).

${ }^{29}$ Wallace 1998: 208-222.

30 Thivel 1994: 72-73. 
lo cual nos conduce a la prevención de cautela que menciona Protágoras (B 4): "Sobre los dioses no puedo tener la certeza de que existen ni de que no existen". Thivel añade que un pronunciamiento de esta naturaleza justificaría la persecución ideológica de Protágoras (no exenta de aristas políticas) dado que la pura discusión sobre la existencia de los dioses resultaría inaceptable en los círculos de influencia religiosa. Al respecto, Lenfant ha defendido la autenticidad del proceso de impiedad incoado a Protágoras ${ }^{31}$. El autor, terciando en un debate abierto por la historiografía actual, comenta los testimonios relevantes e inserta el proceso en el seno de una sociedad cuyos mecanismos de poder sancionan formalmente la libertad de expresión pero distinguen la isegoría de la parresía (en la idea de que el uso legítimo de la palabra no autoriza necesariamente el discurso libérrimo sobre razones de Estado, entre ellas la religión cívica). De hecho, la formulación de Protágoras implicaba la negación de una teología científica, factor que ha destacado con tino Drozdek mediante un artículo de equilibrio interpretativo ${ }^{32}$. El estudioso combina el análisis de los fragmentos B 1 y B 4, en la idea de que el ser humano se muestra incapaz de conocer ontológicamente la realidad divina, lo cual deja al criterio del homo mensura la resolución empírica de los hechos religiosos ${ }^{33}$. Amén de ello, la parquedad de testimonios constriñe a una revisión del Protágoras platónico pero, como el mismo Drozdek admite, resulta imposible determinar si el diálogo presenta las consideraciones genuinas de Protágoras o la exégesis privativa de Platón. De todos modos, Drozdek salvaguarda el interés de Protágoras en los asuntos religiosos, examinados desde su utilidad psicológica y social, ajenos a una significación metafísica. Amén de ello, la atención de Protágoras hacia el problema religioso quedaría acentuada por el libro Sobre las cosas del Hades que, junto a Sobre los dioses, mostraría ese talante inquieto del pensador ${ }^{34}$. Por lo demás, la reconstrucción del pensamiento de Protágoras a partir de testimonios platónicos, como efectúa Zilloli, entraña una labor conjetural con riesgos metodológicos de importancia ${ }^{35}$.

${ }^{31}$ Lenfant 2002. Los procesos de impiedad delataban, aparte la consideración irreligiosa del individuo interesado, una persecución por razones de índole sociopolítica (Drozdek 2007: 118). Es consabida la pertenencia de Protágoras al círculo de Pericles: cf. Bonazzi 2004: 344347. Para una reconsideración crítico-literaria del proceso que habría experimentado el sofista, cf. Corradi 2007.

${ }^{32}$ Drozdek 2005.

${ }^{33}$ Bonazzi (2004: 335-338) presenta asimismo unas líneas específicas sobre la idiosincrasia del homo mensura. No obstante, centra su estudio en las implicaciones políticas del fragmento B 1 y en la adaptación de este al contexto de la democracia ateniense.

${ }_{34}$ Drozdek 2005: 42; 2007: 110-113. En una línea más conservadora, cf. Durán López 2011: 257-276. Desde una posición más radical, cf. Hourcade 2000: 113; 2009: 90. De hecho, Hourcade subraya que, en la tradición doxográfica, el tratado Sobre las cosas del Hades es atribuido tanto a Protágoras como a Demócrito (2000: 107 y n. 71).

${ }_{35}$ Zilioli 2007. El autor reflexiona sobre el tenor del relativismo protagoreo mediante el apoyo en las secciones oportunas del Teeteto y del Protágoras de Platón. Véase una justa reseña a las bondades y límites del ensayo en Miller 2009. 


\section{Pródico}

Es incuestionable que los testimonios y los fragmentos atribuidos al sofista de Ceos han promovido la atención reciente de los especialistas, seducidos por la originalidad de las teorías (ir)religiosas que nuestro pensador refiere. En el seno de los estudios actuales, resulta particularmente incisiva la aportación de Drozdek $^{36}$. Efectivamente, el contenido fascinante del fragmento DK 84 B 5 revela a grandes rasgos que los hombres deificaron inicialmente los elementos nutricios, de utilidad esencial en la vida humana, y posteriormente juzgaron dioses a quienes habían descubierto el poder benéfico de tales elementos. La noticia merece el análisis puntilloso de Drozdek, el cual examina las fuentes antiguas que transmiten el pasaje y enfatiza la novedad sustancial de la teoría: aceptando la doble fase de divinización a la manera de Pródico, los dioses quedarían reducidos a un estatus humano, dioses proclamados tales no por la acción del temor sino del reconocimiento que los propios hombres, agradecidos, habrían tributado. E1 cambio de actitud, el avance experimentado respecto de Protágoras, se antoja inmediato: si el de Abdera admite la existencia de una esfera divina que, no obstante, resulta incognoscible para los seres humanos, Pródico subraya que la religión es una mera invención de los hombres. La reflexión incisiva de Drozdek se resuelve, empero, con este corolario harto especulativo: el sofista, en un implícito delirio de grandeza, pretendería deslizar que la maestría exquisita de su técnica (mediante la correspondiente utilidad práctica para sus contemporáneos) debiera elevarse a categoría divina ${ }^{37}$. $\mathrm{El}$ caso es que esta atención demorada a la figura de Pródico ha permitido saludar recientemente la monografía integral debida a Mayhew quien, con argumentos parcialmente convergentes de los ya expuestos, participa sin ambages del firme ateísmo inherente a nuestro sofista ${ }^{38}$.

En una línea complementaria, autores como Onfray y Durán López se han pronunciado en la actualidad desde posiciones diametralmente antitéticas sobre el esquema contracultural, en el primer caso, o religioso, en el segundo, de Pródico $^{39}$ : una versión moralizante debida a Jenofonte ubica la figura de Heracles en un dilema existencial ante la presencia de sendas mujeres, que simbolizan respectivamente el Vicio y la Virtud, las cuales pugnan por ganar la confianza de

36 Drozdek 2006; 2007: 113-115. A decir verdad, la orientación sobre el ateísmo consustancial de Pródico, que Drozdek defiende con pertinacia, tiene su origen metodológico y programático en los perspicaces estudios de Henrichs 1975; 1976; 1984, especialmente 4046.

${ }^{37}$ Drozdek 2006: 63.

38 Mayhew 2011: 180-183. No obstante, Bett (2013: 300-301), aceptando la tesis de Mayhew, matiza que "to explain how people came to their belief in gods ... is not necessarily to say that gods do not exist".

${ }^{39}$ Onfray 2007: 162-167; Durán López 2011: 314-316. 
Heracles para su causa ${ }^{40}$. Entre juegos y permutas de razonamientos dobles, la Virtud obtiene su propósito, circunstancia que aprovecha Onfray para defender la propuesta de un ejercicio retórico que sancionaría la etopeya del héroe mítico. Por su parte, Durán López acepta la validez moral del relato y proporciona datos adicionales que abogarían en defensa de un interés declarado, inherente a Pródico, por las plegarias religiosas. A nuestro parecer, ambas posiciones adolecen de cierto énfasis en las directrices que postulan. Mientras el análisis del fragmento da pábulo a Onfray para esgrimir el cariz iconoclasta de un Pródico hedonista (condición que el filósofo francés juzga recurrente en la prosopografía del intelectual ${ }^{41}$, la hipótesis que sostiene Durán López se conjetura sobre datos procedentes de una tradición moralizante cuya raigambre socrático-platónica es palmaria ${ }^{42}$.

\section{Critias}

La inclusión de Critias en el círculo de los sofistas es nebulosa. Y, como ha sido justamente indicado ${ }^{43}$, la acreditación de que el memorable fragmento DK 88 B 25 correspondiera a Eurípides y no al controvertido mandatario invalidaría virtualmente la integración de Critias en el movimiento sofístico. Sin embargo, un juicio certero sobre tan vexata quaestio dista de aclarar la paternidad genuina de nuestro precioso texto, el cual postula -resulta consabido- el invento de la religión como arma socialmente coercitiva. Por ello y de manera cautelosa, aceptamos metodológicamente el criterio de convención taxonómica. De hecho, los estados de la cuestión más concienzudos parecían abocar a la suspensión analítica sobre el problema $^{44}$. Nada más lejos de la realidad: las posiciones exegéticas de los últimos años han perseverado en la resolución del enigma mediante interpretaciones renovadas y oscilantes acerca de la autoría y su relevancia, del ateísmo sincero o presunto que el texto destila, de la intención política que anima la composición.

Inicialmente brilla la contribución de Vanotti, quien defiende sin ambages la adscripción a Critias del fragmento DK 88 B 25 (perteneciente al drama satírico Sísifo ${ }^{45}$. La autora ofrece una reinterpretación del personaje histórico con arreglo a su trayectoria intelectual. Así, la colación interna del renombrado pasaje

${ }^{40}$ X. Mem. 2. 1. 20-34 = DK 84 B 2.

${ }^{41} \mathrm{La}$ tesis de Onfray, atractiva en líneas generales, se resiente de un error metodológicamente censurable: en el análisis de los fragmentos atribuidos a Pródico (los cuales no llegan a la decena), el autor omite pasajes susceptibles de contravenir la tesis defendida. Cf. nuestros recelos críticos en Ramón Palerm 2009b: 58.

${ }^{42}$ Durán López (2011: 319-324) asienta las posiciones religiosas de Pródico sobre la base insegura de ciertos diálogos apócrifos.

${ }_{43}$ Melero 1996: 428 n. 52.

${ }^{44}$ Es particularmente modélico Davies 1989.

${ }^{45}$ Vanotti 1997. 
con otros recogidos en la tradición literaria sugiere considerar abiertamente la perspectiva de un Critias pesimista y ateo en forma indivisible. En efecto, el contenido del Sísifo mostraría la ineficacia del vó malvados, lo cual justificaría que un sabio legislador hubiera introducido las potencias divinas como elementos disuasorios. La oportuna confrontación de nuestro fragmento con ciertos pasajes de tono aledaño (DK 88 B 9, B 21, B 22 y B 23) avalaría la consternación de Critias ante la imposibilidad de que reverdeciera la moral aristocrática en contraposición al código democrático, triunfante: ello habría de percutir en una desilusión sociopolítica y, por ende, en tan acerado ateísmo. El modelo explicativo de Vanotti salvaguarda la hipótesis tradicional con perspectiva incisiva y, en una línea de exploración sugerente, Bultrighini integra el fragmento DK 88 B 25 en la arquitectura doctrinal de Critias, el cual pugna por debelar la instrumentalización del poder religioso que detenta el imperialismo democrático ${ }^{46}$. En realidad, Bultrighini juzga el ateísmo inherente al Sisifo como un problema aparente, ante el convencimiento de que esa laicidad ostensible se configura como respuesta a la manipulación propagandística-ahí está el incremento progresivo de los procesos por impiedad- que el régimen democrático ejercía sobre el mundo religioso. En suma, la formulación radical de Critias constituiría el reflejo de su posicionamiento ideológico-político al servicio de una ética aristocrática. Esta orientación crítica ha recibido un sólido apoyo en los trabajos de Caire, autora de una notable monografía sobre el sofista-déspota en el cual se verían conciliadas la metodología sofística y el peso de la tradición aristocrática ${ }^{47}$. Con arreglo a nuestro conspicuo fragmento, Caire concede que la intención primordial del mismo reside en señalar la fuerza de la religión como herramienta represiva del legislador sobre los ciudadanos, al extremo de erigirse este ladino inventor en autoridad cuasidivina ${ }^{48}$.

Incidiendo sobre el problema, Cipolla renuncia al debate sobre la autoría del fragmento, se centra en el examen estricto del pasaje y acentúa el sentido genuino del fragmento, a saber, el ateísmo formal, la inexistencia de los dioses ${ }^{49}$. Sucede que, al decir de Cipolla, un examen intrínseco de cariz léxico permite refrendar el ataque a los fundamentos de la piedad tradicional. De tal forma, el estudioso resume y somete a diatriba sistemática la hipótesis de Pechstein ${ }^{50}$, quien sostiene una interpretación sui generis del pasaje: el texto no anularía la existencia sino la omnisciencia de los dioses.

${ }^{46}$ Bultrighini 1999: 223-231.

${ }^{47}$ Caire 1998.

${ }^{48}$ Caire 2002.

${ }^{49}$ Cipolla 2005: 203. En cualquier caso y como advierte el estudioso, resulta complejo determinar si el personaje de la composición trasluce realmente el esquema ideológico del autor.

${ }^{50}$ Cipolla 2005: 204-219; Pechstein 1998 (apud Cipolla 2005: cf. la apostilla especialmente crítica de 204 n. 12). 
Siendo así el estado de las investigaciones actuales sobre Critias, no han faltado voces, incidentalmente discrepantes, sobre la autoría y el enfoque capital de nuestro fragmento. Por referir las más apreciables: autores como Kahn y Pechstein se muestran frontalmente contrarios a la paternidad de Critias y atribuyen el Sisifo a Eurípides ante la circunstancia -esgrimida con particular celo por Kahn- de que la tesis inherente al Sísifo se compadece bien con el auge del ateísmo teorético que emerge en Jonia y con el entramado intelectual, comparativamente pertinente, de Pródico y Demócrito ${ }^{51}$. Asimismo, existen propuestas de innovación exegética que juzgamos en exceso conjeturales e improbables: al respecto, Santoro maneja para el fragmento el concepto de 'ateísmo presunto', ya que realmente Critias polemizaría contra teorías amorales de ciertos pensadores de la época (entre los que sobresaldría la personalidad de Sócrates) $)^{52}$. Por su parte, O'Sullivan imprime al texto un sello optimista y ahonda en el pragmatismo positivo que, para la recta organización de la humanidad, cobraría la invención de las categorías religiosas ${ }^{53}$.

Referidas estas consideraciones de actualización sobre el movimiento sofístico, nos ajustamos acto seguido a los géneros literarios que han merecido nuestra atención en los comentarios correspondientes al capítulo cuarto del presente libro.

\section{El DRAma}

El teatro griego, en su expresión más sublime, constituye esencialmente una creación cuyo desarrollo está vinculado al sistema democrático de Atenas. Como ha demostrado Suárez de la Torre en un trabajo clarificador de síntesis, la interconexión de tragedia, religión y política es manifiestamente palmaria en la Atenas Clásica ${ }^{54}$. De manera análoga, la comedia política y el drama satírico revelan esa asociación entre el género literario y el factor político-religioso. Por añadidura las tensiones político-ideológicas, de carácter exponencial en la Atenas Clásica, quedarán también exhibidas merced a las antinomias y categorías de signo (ir)religioso que recorren el teatro, con especial incidencia en la tragedia. Por lo demás, la crítica especializada viene insistiendo en que el drama refleja de manera patente los problemas inherentes a la convivencia cívica y a la participación del cuerpo social en la realidad política de la Atenas Clásica ${ }^{55}$.

\footnotetext{
${ }^{51}$ Kahn 1997: 248-262; Pechstein 1998 (apud Cipolla 2005).

${ }^{52}$ Santoro 1997.

${ }^{53}$ O'Sullivan 2011.

${ }^{54}$ Suárez de la Torre 1998. El autor presenta una sinopsis exegética sobre los aspectos capitales del problema y facilita un actualización científico-bibliográfica de relevancia. Cf. asimismo Suárez de la Torre (2016) y Crespo (2016).

55 Sancho 2011: 18-19.
} 


\subsection{La tragedia}

En una colaboración propedéutico-científica, atinadamente expuesta, el profesor Varias ha recabado los datos oportunos que concilian y explican el haz de tensiones (ir)religiosas anejas a la tragedia ${ }^{56}$. Efectivamente, el héroe trágico busca inexorable e irreversiblemente la verdad y, llegada la anagnórisis, encuentra la respuesta doliente a su pesquisa existencial. En consecuencia, asistimos al declive del protagonista cuyo error intelectual ( $\alpha \mu \alpha \rho \tau i ́ \alpha)$, frecuentemente precedido de la obcecación debida a üßpıs, debe ser expiado por atentar al esquema religioso: como bien subrayan Allan y otros especialistas, el motivo religioso se halla indisolublemente ligado al género de la tragedia ${ }^{57}$. El caso es que la proyección de la antinomia 'religiosidad / irreligiosidad' en los tragediógrafos viene constituyendo, entre los estudiosos, una línea de orientación significativamente marcada en los últimos decenios. Debe subrayarse que, frente a los planteamientos metodológicos que dominan en otros géneros o subgéneros literarios, la atención a las cuestiones terminológicas resulta felizmente generosa en el ámbito de la tragedia, merced en buena medida al impulso reciente de meritorias aportaciones críticas.

\subsubsection{Esquilo}

Como queda esbozado, la reflexión sobre el panorama léxico-semántico que jalona la obra de los poetas trágicos resulta imperante en la actualidad. En tal sentido, la selección que conservamos de Esquilo es representativa de la citada tendencia analítica. Es consabido que Esquilo, príncipe de los tragediógrafos áticos, imprime al conflicto trágico una innovación ideológica de importancia trascendental: la justicia humana y la piedad divina quedan identificadas mediante una arquitectura de racionalización donde la díkn se erige en categoría universal de la cual los dioses olímpicos (y Zeus en lugar supremo) son garantes máximos $^{58}$. En efecto, conscientes de que las alteraciones del orden religioso provocan la insolencia ensoberbecida del ser humano, los críticos han ahondado de manera incisiva en el factor operativo y desencadenante de la üßpı que jalona las acciones del héroe trágico ${ }^{59}$. En tal sentido, una conducta de impudicia debe reprenderse para preservar la estabilidad sociopolítica y religiosa. Y, a tales efectos, no se antoja irrelevante el carácter didáctico-moral que presenta el

${ }^{56}$ Varias 2005a.

57 Cf. Allan 2004: 113 y n. 1; Mastronarde 2005: 331-332. Con carácter general disponemos actualmente de un repertorio léxico sobre la tragedia griega: cf. Roisman 2014.

${ }^{58}$ Varias 2005b.

59 La monografía de Fischer (1992) constituye el hito que nutre metodológica y fundamentalmente los estudios más acreditados sobre el problema híbrico. Con base en el estudio de Fisher, debemos saludar particularmente las contribuciones de Cairns (1996) y de Moreau (1997). 
restablecimiento del orden conforme a justicia. Esta es la línea de interpretación que persigue Ramelli mediante un puntilloso estudio sobre el pensamiento teológico y ético de Esquilo: para la autora, la üßpıৎ encubre permanentemente en la producción esquílea una culpa humana que autoriza la punición de la falta cometida, una sanción justa que emite una divinidad justiciera mas no envidiosa e indiferente a los asuntos del hombre, como ocurría en el modelo grecoarcaico ${ }^{60}$. Con todo y en buena lógica, el problema de la űpıs ha percutido de manera más dilecta en ciertas tragedias: así ha ocurrido con Los Persas, donde la actitud bibrica de Jerjes (que deploran acerbamente Atosa y la sombra de Darío, sus progenitores incursos en la estructura argumental) se juzga la causa primordial del desastre de los bárbaros en su intento desaforado por conquistar Grecia. La pieza (no exenta

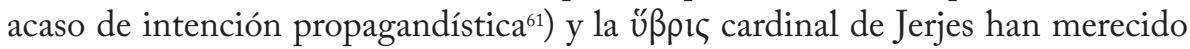
el análisis de Papadimitropoulos en términos de transgresión ominosa-propia de una juventud sobremanera impetuosa- a los preceptos filosóficos de mesura con

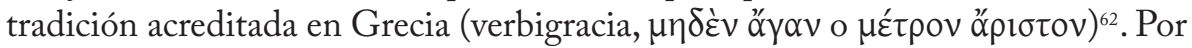
su parte, Leite (en una línea metodológica que explora celosamente la autora) ha facilitado una reciente contribución con una orientación parcialmente paralela a las antedichas ${ }^{63}$. En este caso verificamos los paradigmas de Agamenón ${ }^{64}$, Los Siete contra Tebas y nuevamente Los Persas (obra que asume particularmente el onus probandi de la tesis) a fin de corroborar que la üßpis inherente a ciertos gobernantes y la ofensa divina que esta conlleva es causa motora de la acción trágica y de la consiguiente ruina para la ciudad pertinente. Como era de esperar, el castigo correspondiente por tan irreligiosa falta es juzgada como la reparación de la justicia por obra de Zeus. Esta circunstancia explica asimismo que Bees repute la obra desde una perspectiva eminentemente teológica, ya que el triunfo de la libertad sobre el despotismo se vería acompañado por la victoria de la divinidad sobre las fuerzas sacrílegas ${ }^{65}$.

Con todo, el hecho de que la űßıৎৎ aparezca en numerosas obras de Esquilo, que se interprete la misma incidentalmente unida a cierta piedad disturbada (Eu. 534) o que incluso en una pieza singular (Prometeo encadenado) Zeus, dios y juez supremo, no aparezca de entrada como garante de la punición híbrica

${ }^{60}$ Ramelli 2008: 153-161.

${ }^{61}$ En el seno de los estudios sobre la tragedia esquílea (y sobre la tragedia griega en su conjunto) existe una vía analítica que tiende a enfatizar la defensa de los valores sociopolíticos que encarna la Atenas del siglo V a.C. Para una actualización crítica del problema (diríase hipercrítica, habida cuenta las conclusiones negativas que el estudioso ofrece sobre la cuestión), cf. Conacher 2000.

${ }^{62}$ Papadimitropoulos 2008.

${ }^{63}$ Leite 2014b.

${ }^{64}$ Asimismo Maslanka Soro (1995: 116-117) y Helm (2004) subrayan la incidencia del

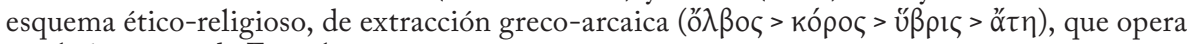
en el Agamenón de Esquilo.

${ }^{65}$ Bees 2009, especialmente 48 y 310. 
sino más bien como un tirano ${ }^{66}$, justifican contribuciones que espigan en direcciones perspicaces: ahí está la posibilidad-meramente conjetural- de que el tragediógrafo sufriera persecución por impiedad (resulta notable la aportación de conjunto que Myriam Librán ha dedicado a las fuentes sobre el problema ${ }^{67}$ ) y, muy especialmente, debe subrayarse la exégesis reflexiva sobre el cariz conceptual de la terminología religiosa (e irreligiosa también) en Esquilo. Al respecto, debemos saludar sendas publicaciones de factura metodológicamente plausibles. Así, el profesor Calderón Dorda ha incidido en una propuesta de índole léxicosemántica aplicada al conjunto de la producción esquílea ${ }^{68}$ : el caso es que un estudio concienzudo de las relaciones que se establecen en la red familiar del rey Agamenón revela conclusiones notables. En efecto, la resolución del basileús para sacrificar a su hija Ifigenia es calificada como $\delta v \sigma \sigma \varepsilon \beta \tilde{\eta} . . . ~ o ̛ ́ v \alpha \gamma v o v, ~ \alpha ̉ v i ́ \varepsilon \rho o v$ (A. 219-220); el Coro proclama que el homicidio sufrido por Agamenón se ha

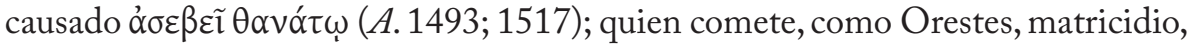

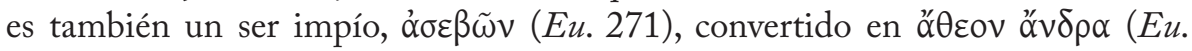

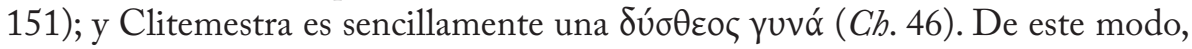

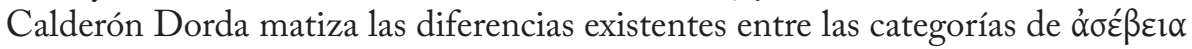
y $\delta \cup \sigma \sigma \varepsilon ́ \beta \varepsilon l \alpha$ que muestra Esquilo: la primera incide en el talante irrespetuoso contra principios religiosos de carácter especialmente familiar (con especial énfasis en el parricidio); la segunda se compadece con actos impíos de índole menor, subrayando la existencia de una piedad desordenada ${ }^{69}$. Por su parte, Ana Vicente ha efectuado un minucioso estudio sobre el tratamiento coherentemente funcional de la $\alpha$ $\sigma \varepsilon ́ \beta \varepsilon l \alpha$ en Esquilo, atendiendo particularmente a su presencia en Los Siete contra Tebas, Las Suplicantes y La Orestia ${ }^{70}$. De este modo, la ơó́$\beta \varepsilon 1 \alpha$ responde a una contravención irreligiosa de los preceptos elementales en el ámbito de la hospitalidad, de la familia, de la veneración a los dioses. Esa ofensa, en definitiva, se contrapone drásticamente a la $\theta \varepsilon ́ \mu ı$ imperante en el esquema cultural y normativo de la sociedad ateniense.

\subsubsection{Sófocles}

Resulta casi proverbial, en el curso de la literatura griega sobre los trágicos, incidir en que Esquilo es el teólogo por excelencia; Eurípides, el filósofo;

${ }^{66} \mathrm{Cf}$. la sugestiva caracterización de los personajes principales (Prometeo y Zeus) que presenta Calderón Dorda 2015b: XXXVIII-XLIV, con la explicación del conflicto trágico inherente a la pieza.

${ }^{67}$ Librán Moreno 2004.

${ }^{68}$ Calderón Dorda 2013. La selección de ejemplos, convenientemente contrastados, parece

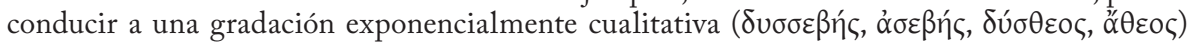
que tiende, como indicábamos al inicio de este capítulo, a esa proximidad semántica entre

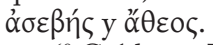

${ }^{69}$ Calderón Dorda 2013: 309-310.

${ }^{70}$ Vicente Sánchez 2015. 
Sófocles, el defensor piadoso de la religiosidad tradicional. Ha sido indicado, con razón innegable, que hablar de Sófocles sin hablar de los dioses es imposible. En realidad, la producción de Sófocles se halla transida del respetuoso temor que la divinidad infunde; y ello por un factor capital: el desconocimiento esencial que los seres humanos albergan respecto de los designios que los dioses tienen proyectados. De este modo, la religiosidad universalmente admitida para nuestro autor cobra su máxima expresión en la óptica purificadora y moralizante de la religión tradicional ${ }^{71}$. La mencionada reflexión, a grandes rasgos aceptable, ha cobrado en la investigación reciente sobre el tragediógrafo líneas de orientación prudentemente adaptadas al estudio de la esfera religiosa con arreglo a dos criterios básicos: el examen sincrónico de la realidad (ir)religiosa que Sófocles transmite, ajena a interpretaciones anacrónicas y aun distorsionadoras, y el análisis concomitante de las categorías léxico-semánticas pertinentes en la obra sofoclea. A decir verdad, las aportaciones de relieve son más cualitativa que cuantitativamente significativas. En buena medida, los estudios de importancia insisten en lo que, con cierto oxímoron, podríamos denominar el agnosticismo moralizante y pragmático de Sófocles. Habida cuenta la crisis espiritual propia del siglo $\mathrm{V}$ a.C. $\mathrm{y}$ la existencia de esa religiosidad grecoarcaica-imbricada en el pensamiento sofocleo-, las contribuciones de Holt y de Parker han insistido en la atención doble de Sófocles tanto a la religiosidad tradicional de las leyes no escritas cuanto a la asunción de una religión inseparable del marco normativo que la polis impone ${ }^{72}$. Como subraya Holt, "Tragedy is the polis's partner in an intricate dialogue" ${ }^{73}$; y el propio título del estudio que Parker efectúa es harto revelador sobre la manifestación del hecho numinoso en Sófocles: "Through a Glass Darkly". Efectivamente, la opacidad de los propósitos divinos (un factor que ha valorado también Pucci con mirada penetrante ${ }^{74}$ ), la observancia de la

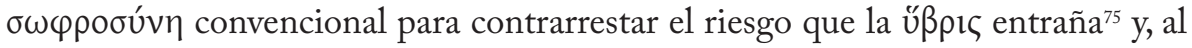
unísono, la consideración debida a la 'religión de Estado' sitúan a Sófocles en una posición delicada, la cual puede inferirse de sus composiciones. En tal sentido, es probablemente Antígona la tragedia que ha suscitado el mayor debate de envergadura filológica (por cierto que no debe menoscabarse el papel fundamental que, en el desarrollo del conflicto trágico, desempeñan las heroínas de Sófocles: entre otros, los casos de Electra o de Yocasta resultan, por acción u omisión, paradigmáticos $\left.{ }^{76}\right)$. Con todo, sucede que Antígona presenta el ejemplo canónico de una religiosidad tradicional confrontado a una religiosidad políticamente

\footnotetext{
${ }^{71}$ Varias 2005c.

${ }^{72}$ Holt 1999; Parker 1999.

${ }^{73}$ Holt 1999: 661.

${ }^{74}$ Pucci 1994.

${ }^{75}$ Lauriola 2007: 405; 2008: 221-222 y 228.

${ }^{76}$ En general, cf. Foley 2001.
} 
correcta. En efecto, los estudios actuales enfatizan la ausencia de una pietas natural, que simbolizaría Antígona, como reverso de una impietas aneja a Creonte. Muy al contrario: Sófocles presenta en toda su complejidad la fusión coexistente de la tipología religiosa antedicha ${ }^{77}$; y Creonte -garante de la religión pública- no es tildado de impío en la pieza trágica. En realidad, las nociones de religión y moral son renuentes a una separación distinguida en el mundo de Sófocles, circunstancia que justifica la recentísima contribución del profesor Calderón Dorda a propósito del entramado terminológico dominante en la producción de Sófocles ${ }^{78}$; y es que un examen comparado del léxico (ir)religioso que opera en las tragedias posibilita la intelección de los problemas pertinentes. Mediante un examen puntilloso de

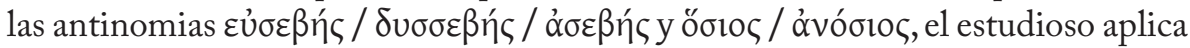
una metodología de feracidad conclusiva, asimismo desarrollada en los casos de Esquilo y de Eurípides: la definición del sustrato religioso que subyace en la obra de Sófocles debe estudiarse desde el análisis que proporcionan las oposiciones de los lemas (ir)religiosos. Al respecto, Calderón Dorda desprende algunas inferencias de interés, a saber, que los términos citados abarcan las tensiones de índole religiosa presentes en las tragedias sofocleas (con especial hincapié en Antigona y en Edipo Rey, sin perjuicio de otras piezas ${ }^{79}$ ); que el par antitético

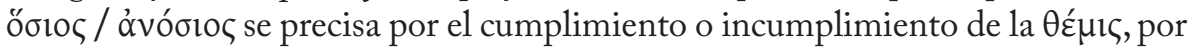
la adecuación o inadecuación de los deberes normativos hacia las divinidades, por la consideración o desconsideración religiosa. En suma, Calderón Dorda incide en que el vocabulario (ir)religioso de las tragedias sofocleas permite delimitar los puntos cardinales del conflicto trágico y fijar los tres niveles esenciales del

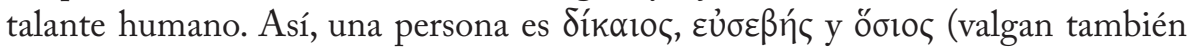
los antónimos) en relación, respectivamente, con sus propios congéneres, con los dioses y con los muertos.

\subsubsection{EuríPIDEs}

Eurípides es autor renuente, como pocos, a una interpretación unilateral en todos los polos de su producción literaria ${ }^{80}$. Se trata de un factor que la crítica histórico-filológica admite de manera resueltamente unánime. Siendo ello así,

${ }^{77}$ Por añadidura, Suárez de la Torre (2006: 25-26), en el seno de un debate notable sobre la pertinencia de considerar una 'religión literaria' hipotéticamente contrastada a una 'religión popular', ha recogido la idea de que la tragedia constituye el ámbito donde el discurso religioso de los atenienses cobra una particular exploración. Asimismo, cf. Suárez de la Torre 2009: 77-79.

${ }^{78}$ Calderón Dorda 2016a. Como bien subraya el autor, "no se puede separar la religión

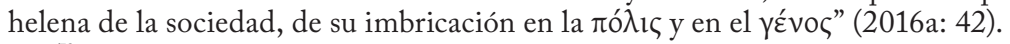

${ }^{79}$ Sobre la antítesis 'racionalismo / religiosidad' en Edipo Rey son meritorias las aportaciones de Bañuls Oller - Crespo Alcalá (2000), Anagnostopoulos (2002-2003) y Ahrensdorf (2009). Resulta en especial incisivo el estudio de Ahrensdorf (2009: 82-84), quien subraya -de manera notablemente innovadora- los peligros de incurrir tanto en una pasión religiosa de ceguera cuanto en un racionalismo político de ingenuidad que infravalore el poder de los preceptos religiosos.

${ }^{80}$ Cf. Vicente Sánchez 2007: 4. 
las reflexiones del tragediógrafo en torno a los problemas religiosos o sobre la relación que se establece entre los dioses y los hombres han venido experimentado la propuesta de ciertos planteamientos que pasamos a sintetizar.

De entrada, existe una tendencia marcada a reinterpretar la religiosidad de Eurípides con arreglo a posiciones que escapan a la consideración ateísta del dramaturgo, una valoración que, con base en el estudio clásico de Verrall ${ }^{81}$, hacía de Eurípides un debelador radical de los dioses convencionales. De este modo, ya Kovacs reivindicaba, con un penetrante trabajo sobre Medea, que las numerosas referencias a los dioses y, en particular, la solución trágica que arrostran los personajes de Jasón y Medea conforman el entramado de "a theological background" donde la acción de Zeus responde a una planificación coherente de la divinidad en el curso de la pieza $^{82}$. El mismo Kovacs incidía en el papel que este designio divino desempeñaba para instrucción del auditorio y, en cierta manera, preludiaba dos contribuciones de extraordinaria importancia, debidas a Sourvinou-Inwood, donde la estudiosa presenta un panorama de sólida hipótesis ${ }^{83}$ : las divinidades de la tragedia, especialmente en Eurípides, no son construcciones meramente artificiales, ajenas a las que el público ateniense mostraba su devoción respetuosa. Al contrario, el hecho de que los personajes trágicos se hallen en contacto directo con los dioses justifica su participación de una realidad y creencia sentidamente religiosas. Una proposición inherente a la tesis de Sourvinou-Inwood redunda en que la exploración de los dioses y de la religión de la polis no debe confundirse con la crítica frontal al esquema religioso. Por cierto que la relación autor-personajes-público resulta fundamental en la aportación de Kindt, quien examina las ambigüedades estructurales anejas al Ión de Eurípides para demostrar que el impacto de los dioses en la humanidad ofrece una perspectiva religiosa donde las potencias divinas se conducen con las mismas contradicciones que la sociedad en su conjunto ${ }^{84}$. Al cabo, el desarrollo incoherente de la acción por parte de Apolo (el cual recibe las imprecaciones de los personajes), las tensiones entre Ión y Creusa, la presencia final de Atenea como dea ex machina para solventar el conflicto trágico, penetran con fuerza dialéctica en los espectadores ${ }^{85}$. Así las cosas, las paradojas exegéticas, la falta de sistematicidad que a menudo destila la obra de Eurípides, la crítica incidental del autor a los dioses del panteón olímpico, han revertido en trabajos meritorios, centrados en el examen de un Eurípides ecléctico, proclive a la formalización de héroes y dioses secularizados los cuales se exhiben ante la sociedad. Ello insta

${ }^{81}$ Verrall 1895. Puede observarse un estado de la cuestión sobre el particular en Wildberg 2002: 1-11.

${ }^{82}$ Kovacs 1993. En general, cf. recientemente Lefkowitz 2016.

${ }^{83}$ Sourvinou-Inwood 1997 (en especial 184-186); 2003.

${ }^{84}$ Kindt 2007.

${ }^{85}$ Muñoz Llamosas 2002: 112-113; Calderón Dorda 2015a: 41. 
a una profundización revisada del concepto de piedad sin merma del contexto religioso que persiste resignada, paralelamente al orden racional. Para ser más

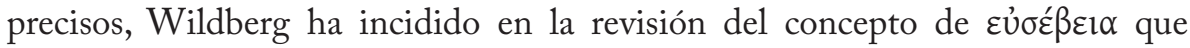
emana de las obras de Eurípides, detectable igualmente en otros intelectuales de la época. A su entender, el concepto de piedad trasciende la mera servidumbre acrítica de los hombres hacia los dioses para conformarse como un servicio de reciprocidad, en la idea de que los actos humanos y divinos son interdependientes. Por consiguiente, esta noción de piedad eleva el estatus intrínsecamente moral y ontológico de los hombres, quienes se presentan, en palabras del autor, "vis-à-vis the inmortal gods" ${ }^{86}$. Por su parte, Zeilfelder, con base en Las Troyanas, Lawrence y Papadopoulou (en estos dos estudios con particular atención a Heracles) han convenido en el proceso de secularización que Eurípides imprime a los héroes trágicos ${ }^{87}$. Especialmente en el ejemplo de Heracles asistimos al reconocimiento en el personaje (y en los espectadores) de que debemos vivir a la manera más justa posible en un mundo que muestra la incoherencia de unos dioses frecuentemente hostiles hacia los hombres ${ }^{88}$. Con todo, la crítica subyacente al modus operandi de las divinidades resulta en última instancia irrelevante, dado que el esquema religioso permanece esencialmente invariable ${ }^{89}$. Como era de esperar, estas reflexiones tienen su correlato en contribuciones de notable mérito, las cuales enfatizan que el universo creativo de Eurípides presenta la existencia de unos dioses cuyas pautas morales repugnan al dramaturgo. El caso es que Ostwald, mediante una exposición general, y Vela, más pormenorizadamente mediante una selección ilustrativa de pasajes, han espigado con tino en el escepticismo que muestra Eurípides respecto de la religión tradicional ${ }^{90}$ : esa circunstancia favorece, en buena lógica, una dinámica exponencialmente pesimista en la obra de Eurípides que, como ha expresado Muñoz Llamosas (con especial hincapié en el sentido último de Las Bacantes), permite inferir la pertenencia de los ámbitos religioso y racional a esferas distintas; $y$ la doliente conclusión de que, pese al acumen del orden racional, la epifanía de los dioses se revela poderosamente omnímoda ${ }^{91}$. Pues bien, los aspectos susodichos (noción renovada de la piedad, crítica sobre la moralidad de los dioses olímpicos), entre otros de fuste, se conjugan en un sugestivo artículo de Calderón Dorda quien, con una metodología inductiva de tenor léxico-semántico, presenta el corpus relevante de los lemas (ir)religiosos

\footnotetext{
${ }^{86}$ Wildberg 1999-2000: 235-236.

${ }^{87}$ Zeilfelder 1991; Lawrence 1998; Papadopoulou 2005.

${ }^{88}$ Lawrence 1998: 145.

${ }^{89}$ Papadopoulou 2005: 128; Cf. asimismo Matthiessen 2010b: 154-157.

${ }^{90}$ Ostwald 1999; Vela Tejada 2012.

${ }^{91}$ Muñoz Llamosas 2002. La autora comenta con perspicacia (110-113) la incidencia paulatina en la producción de Eurípides de la $\tau u ́ x \eta$, ocasionalmente opuesta al poder divinal (si bien no absolutamente desligada del mismo). En sentido parejo, deben considerarse debidamente las agudas observaciones de Giangrande 2011: 164-165.
} 
que operan en la producción toda de Eurípides: estos muestran, a la postre, una

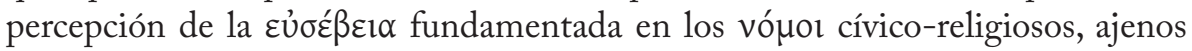
a cualquier abstracción, donde la piedad y la justicia socio-religiosa se hallan ligadas ${ }^{92}$.

\subsection{El drama satírico}

El conocimiento ciertamente limitado de que disponemos sobre el drama satírico ha repercutido en un interés restringido, con carácter general, a los aspectos estructurales, tópicos y analíticos sobre los fragmentos que la tradición nos ha legado y, como es lógico, sobre las características tipológicas que presenta El Cíclope de Eurípides, único drama conservado en su integridad. No obstante, algunas aportaciones de la crítica reciente han subrayado las características (a) teístas permeables en ciertas obras o personajes relevantes con el propósito de establecer esa oposición (que el subgénero presenta de forma vehemente) entre la acción civilizadora del espacio político, sostenedora del esquema religioso imperante, y la presencia incivilizada del mundo agreste, singularizada por el desprecio de las normas religiosas: este segundo tema consta de forma groseramente palmaria merced a la etopeya que presenta Polifemo en El Ciclope. Con todo, es verdad que el drama satírico (la celebrada 'tragedia en broma', así definida por Demetrio en Sobre el estilo) trasluce incidentalmente el argumento jocoserio de una paradoja risible, las limitaciones inherentes a los dioses: esta circunstancia ha sido subrayada por Sanchis Llopis en un instructivo trabajo de conjunto ${ }^{93}$. Sobre el particular, ya Sófocles presenta en Los Rastreadores (la obra fragmentaria del dramaturgo más extensa hasta la fecha) a un atribulado Apolo quien, considerando el robo de su ganado vacuno por obra de Hermes, se granjea mediante promesas dadivosas el apoyo de Sileno y los suyos a fin de recobrar las cabezas de ganado. Sin embargo, es El Cíclope de Eurípides la pieza que ejemplifica, paradigmáticamente, la oposición antedicha 'civilización vs. barbarie': la acción, ubicada en Sicilia, nos presenta a un Odiseo resuelto que, con la ayuda de unos pusilánimes sátiros, completará la justa venganza (restableciendo así el orden normal de las cosas) del sacrilegio feroz cometido por el gigante: la ingesta de carne humana, el sacrificio de los compañeros. No solo es significativo, por su violencia blasfema, el discurso ateísta del Cíclope (vv. 316-340), donde el ogro blasona de no servir a otro Zeus que a su propia panza, en la idea de que riquezas y placeres sin cuento constituyen la única divinidad a la que deben rendir tributo los prudentes. A decir verdad, resulta más escabroso el parlamento del Cíclope en los versos 382-408, cuando Polifemo

\footnotetext{
${ }^{92}$ Calderón Dorda 2015a.

${ }^{93}$ Sanchis Llopis 2010: 18.
} 
expone (en un episodio bien estudiado por García González ${ }^{94}$ ) una inversión macabramente paródica del ritual griego por excelencia, el sacrificio ${ }^{95}$. En efecto, el rito antropofágico supone la deglución no solo de los compañeros sino de las instituciones políticas y religiosas de la ciudad. La restitución normativa de Odiseo cuenta con el soporte adicional de los sátiros los cuales, identificados como devotos de Dioniso, apelan a un encantamiento o conjuro de Orfeo para derribar la presencia enemiga del Cíclope (vv. 646-648). En sugestiva hipótesis de Faraone, ello se relacionaría con cultos mistéricos de inspiración órfica ya que, en definitiva y como queda dicho, los sátiros reverencian a Dioniso y la acción dramática tiene lugar en Sicilia, un reconocido centro de culto órfico ${ }^{96}$.

\subsection{La comedia aristofánica}

El panorama crítico-científico de los autores modernos (y de los antiguos) sobre la incidencia del fenómeno irreligioso en Aristófanes ha resultado notablemente parco. Una sucinta ojeada al repertorio bibliográfico de Winiarczyk es harto elocuente ${ }^{97}$ : hallamos diez referencias; $y$ en la literatura antigua no hay mención relevante de presunción ateísta para el comediógrafo ${ }^{98}$. El caso es que, como ha expresado justamente Perrone, "una valutazione complessiva del rapporto di Aristofane con la religione resta a tutt' oggi un desideratum nell' àmbito degli studi moderni sulla commedia antica"99.

A decir verdad, las líneas de interpretación sobre el posicionamiento (ir) religioso de Aristófanes han oscilado entre la concepción del factor religioso como reflejo histórico-cultural de una estricta ritualización y la consideración del problema con arreglo al carácter comprometido políticamente de la comedia aristofánica ${ }^{100}$. Con todo, en los últimos decenios hemos asistido a tres modelos explicativos que han pugnado crecientemente por explicar el enfoque de Aristófanes con los resultados que acto seguido destacamos:

1. A principios de los años noventa, Corsini reelabora con reflexiones renovadas la tesis que el estudioso italiano había propuesto a finales de los ochenta ${ }^{101}$. En esencia, Corsini propugna que la hostilidad de Aristófanes contra la 'religión de Estado' es permanente e incisiva en el curso de toda su producción.

${ }^{94}$ García González 2008: 80-81.

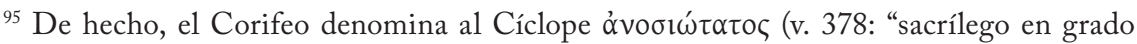
sumo") en la antesala de este episodio donde, como ha estudiado exquisitamente Palmisciano (2008: 72-74), el ogro se conduce con toda su ferocidad y degradación.

${ }^{96}$ Faraone 2008.

${ }^{97}$ Winiarczyk 1994: 30-31.

${ }^{98}$ Winiarczyk 1984.

${ }_{99}$ Perrone 2006: 111.

100 Perrone 2006: 111-112.

${ }^{101}$ Corsini 1993. Precisamente Winiarczyk (1994: 31) presenta la colaboración inicial de Corsini (1986) como última entrada bibliográfica en el apartado referente a Aristófanes. 
Ya en su primera etapa, con Los Caballeros, se verifica la ridiculización crítica de las sentencias oraculares, puesto que la manipulación de los oráculos permitirá a Paflagonio-Cleón regir los destinos de la ciudad hasta que el Morcillero, individuo de ínfima calaña y más deshonesto si cabe, le reemplace en el gobierno de la polis. Sucede que -indica Corsini-Zeus y Atenea son los protectores respectivos de Cleón y del Morcillero. Asimismo, es frecuente que los héroes cómicos perciban hacia ellos la aversión de los dioses oficiales, de la religión institucional: ello resultaría de suyo evidente en plena madurez creativa del comediógrafo con Las Nubes y Las Aves, donde se propone la sustitución de las divinidades convencionales del panteón por divinidades alternativas. Por otra parte, $\mathrm{La} \mathrm{Paz}$ muestra que únicamente el empeño declarado del buen Trigeo posibilita la liberación de $\mathrm{Paz}$ (secuestrada factualmente por los dioses) y su restitución al conjunto de los pueblos griegos. Para finalizar, la etapa postrera de Aristófanes brinda una pieza, Pluto, representativa de ese Zeus impotente ante la pujanza del dios crematístico, el cual impondrá entre los atenienses la equidad distributiva que las divinidades olímpicas han sido incapaces de establecer. En suma, Corsini infiere sendas conclusiones básicas: que Aristófanes dista de erigirse en paladín de la religión tradicional; y que el comediógrafo pretende denunciar la colusión de los aspectos religiosos y políticos del Estado, de suerte que la ofensiva de Aristófanes contra la 'religión de Estado' es complementaria de su animosidad hacia la 'política de Estado'.

2. Con planteamientos parcialmente convergentes en Corsini, el profesor Gil facilita un esquema analítico que subraya la ambigüedad de Aristófanes en su actitud (ir)religiosa, la cual patentiza una división marcada entre la religión estatal y la religión individual102; y es que un objetivo nada desdeñable en la estrategia dramatúrgica de Aristófanes era subvenir a los distintos sectores de la población. La distinción estructural (ausente en el modelo de Corsini) explica que el comediógrafo, en consonancia con los intelectuales más señeros de su época, juzgue la religión olímpica como elemento de cohesión panhelénica mas, en realidad, pura falacia mitológica. Por consiguiente, este enfoque justifica que Aristófanes se muestre inexorable con los dioses oficiales, las divisas oraculares, los ritos adivinatorios (Las Aves constituye un paradigma sobre el particular): emblemas que, abusivamente tergiversados por los representantes del fanatismo religioso, desnaturalizaban las manifestaciones populares de religiosidad. Por contra, Gil enfatiza el respeto exquisito de Aristófanes por el casticismo religioso de los atenienses, lo cual impide el menor comentario lesivo sobre Atenea, Teseo o -muy significativamente- los misterios eleusinos ${ }^{103}$. En resolución,

102 Gil 1996: 91-98.

${ }^{103}$ Por cuanto concierne a la penetración del rito eleusino en la identidad religiosa de los atenienses, cf. Suárez de la Torre (1997) con base en Las Ranas de Aristófanes. 
Gil acepta el estudio per se de la crítica religiosa, acentúa la antinomia 'religión oficial / religión individual' y opta por incluir al comediógrafo en la órbita del "agnosticismo religioso"104.

3. Por otra parte, es mérito de Perrone haber trazado una convincente panorámica sobre las tendencias operativas más incisivas en la perspectiva (ir) religiosa de Aristófanes ${ }^{105}$. En el curso de una revisión puntillosa que trasciende la orientación estrictamente religiosa del comediógrafo, la estudiosa se decanta cautelosamente por la propuesta de métodos eclécticos que posibiliten explorar los distintos niveles de lecturas inherentes a las piezas cómicas. En realidad Perrone, quien comenta las tesis de impacto tradicional sobre la cuestión, limita el valor de los estudios socio-antropológicos y de índole carnavalesca que, mediante la sanción de la ritualización genérica o la relajación temporal del orden establecido, adscriben las comedias a una sola estructura en corroboración de la religión convencional. El caso es que Perrone menciona los análisis de corte antropológico-estructuralista y saluda particularmente la irrupción de estudios que justiprecien los elementos crítico-cómicos ${ }^{106}$, en la idea de que la comedia aristofánica persigue satisfacer las exigencias de un público ideológica y socioculturalmente distinguido. En cualquier circunstancia, Perrone juzga reduccionista la interpretación de la (ir)religiosidad aristofánica con arreglo a dicotomías inadecuadas, a saber, 'teísmo / ateísmo', 'reacción / progreso', 'irracionalismo / racionalismo'.

Al compás de las posiciones metodológicas aquí comentadas, resulta obvio que persiste la espinosa cuestión sobre Aristófanes y su modus operandi en relación con el esquema religioso de la época. Por nuestra parte creemos que, en la dirección discursiva de Gil y de Perrone, puede atenderse de manera singular al enfoque de la (ir)religiosidad en Aristófanes mediante el análisis cuidado de la dialéctica 'emisor / receptor'. En efecto, se antoja conveniente una indagación del problema con base en criterios sincrónicos, puesto que el poeta compone para un público de estatus dispar, en un momento concreto de la realidad ateniense, merced al contexto de un canal comunicativo ${ }^{107}$. Expresado

${ }^{104}$ Gil 1996: 97. En un trabajo de erudición complementaria, Gil (2002: 177) comenta ciertos decretos de la época con resoluciones restrictivas sobre la libertad crítica del comediógrafo.

105 Perrone 2006: 116-119.

${ }^{106}$ Cf. Bowie 1993, quien de modo pionero sugiere varios niveles de lectura para las distintas composiciones en un ensayo global de la comedia aristofánica. Por añadidura, Silk (2000) exhibe un trabajo paradigmático que aquilata el tratamiento de los elementos crítico-cómicos. Los trabajos citados en esta nota merecen el interés de Perrone (2006: 118). No obstante, debemos significar que los estudios de Bowie y de Silk no se circunscriben al problema religioso.

${ }^{107}$ En una sugestiva colaboración, publicada de manera póstuma, López Eire (2014: 85-90) documenta ciertos pasajes de Aristófanes referentes, en su contexto adecuado, a las concepciones religiosas de la época. 
en otras palabras, juzgamos plausible la aproximación al comediógrafo como autor de una obra que presenta esa polivalencia semántica con estratos de lectura parcialmente divergentes, ligados a las inquietudes del espectador. De este modo, interesa espigar en la tensión 'religiosidad / irreligiosidad' que recorre las piezas; en la relación que los personajes de las obras mantienen a propósito del hecho (ir)religioso para, mediante un proceso inductivo, obtener en lo posible respuestas sobre la planificación conjunta de Aristófanes, a menudo transida de una ambigüedad conscientemente calculada ${ }^{108}$. Por lo demás, conviene una elemental cautela sobre ciertos aspectos plasmados en la crítica moderna. Así, el esfuerzo glosado de Corsini puede inducir a sendos riesgos metodológicos. Por un lado, la fusión objetiva entre la crítica política y la crítica religiosa insta a menoscabar los aspectos cómicos y, por otro, es inexacta la identificación, en la Atenas finisecular, entre ideología conservadora y defensa de la religión tradicional; entre aperturismo político y censura del panteón olímpico; e incluso entre posiciones reaccionarias y hostilidad hacia la 'religión de Estado' (acaso adulterada por acción de las autoridades democráticas): ciertamente esas variantes combinatorias -entre otras factibles- comparecen en el siglo $\mathrm{V}$ a.C., pero debemos mostrarnos escrupulosamente precavidos al respecto. A su vez los análisis de carácter antropológico-estructural se revelan insuficientes si, como en el caso de Bowie, contemplan la existencia de microestructuras internas de la obra que posibilitan descodificar la lectura primera del receptor. De esta guisa, la composición se convierte en un puzle cuyas piezas debe encajar discretamente el espectador-lector ${ }^{109}$. En fin, por cuanto antecede parece deseable una orientación metodológica que, como quiere Perrone, aprecie el diálogo entre el autor y el receptor de la obra al tiempo que pondere combinadamente los aspectos jocoserios en la dimensión (ir)religiosa de la comedia aristofánica ${ }^{110}$.

\section{LA ORATORIA}

Es consabido que, en la Atenas Clásica y tras la formalización paulatina de una oratoria retórica, asistimos a la consolidación de los géneros oratorios. No obstante los trasvases retórico-técnicos que estos experimentan, resulta aceptable la categorización reglada en la Atenas finisecular de los tres géneros por excelencia: el epidíctico, el judicial y el deliberativo con sus respectivos

${ }^{108}$ Un intento de esta vía interpretativa, ajustado a Las Tesmoforiantes, puede contrastarse en Ramón Palerm 2014b.

${ }^{109}$ La reseña de Sommerstein (1994: 88-89) analiza con mordacidad crítica el volumen de Bowie 1993.

${ }^{110}$ En esta línea exegética, cf. Cottone 2005. La autora defiende convincentemente la atención equilibrada de los aspectos crítico-cómicos para el estudio capaz de la comedia aristofánica. 
exponentes de relevancia máxima: Gorgias, Antifonte y Andócides ${ }^{111}$. Como es lógico, la condición distinguida de los autores y la consideración bifaz e indivisible de Gorgias y de Antifonte (en su calidad de sofistas y oradores, sin perjuicio obviamente de su perfil ideológico-literario) dificulta un análisis monolítico de la oratoria con arreglo a posiciones de índole (ir)religiosa ${ }^{112}$. El caso es que la naturaleza de las composiciones discursivas inherentes a nuestros autores ha ocasionado que el análisis crítico se haya centrado de manera notablemente restringida a Gorgias y, en modo exponencialmente creciente, respecto de Antifonte y de Andócides.

\subsection{Gorgias}

La oratoria epidíctica se vio ennoblecida merced al cuidado de la sofística y a la pujanza de la sutileza dialéctica. Por ello, la acuñación convencional del género ha recaído en Gorgias, el orador-sofista de mayor refinamiento estructural, quien hizo del encomio formal un modelo literaturizado cuya influencia resultó máxima para el devenir de la prosa artística en Grecia. De hecho, esa exquisita elegancia en el estilo, en la $\lambda \varepsilon^{\prime} \xi ı \varsigma$, constituye la técnica, la exigencia y el objetivo absolutamente prioritarios de Gorgias. En efecto, juzgamos que toda valoración sobre la producción gorgiana (desde cualquier perspectiva que se adopte) debe atender y acaso supeditarse a un factor difícilmente controvertible: Gorgias es el paladín genuino -que tiene su correlato en Antifonte- de la experimentación sobre el arte de la palabra al servicio incluyente del antidogmatismo intelectual. A decir verdad, los estudios recientes sobre nuestro orador inciden raramente en sus inquietudes acerca de la materia religiosa. Con la excepción de sus discursos epidíctico-judiciales (los celebérrimos Defensa de Palamedes y Encomio de Helena), la obra de Gorgias es conocida de manera imperfecta, indirecta y fragmentaria: de esta suerte, el debatido ensayo Sobre el no ser y el Epitafio han merecido la atención de la crítica con intención y óptica distinguidas. En lo relativo al tratado Sobre el no ser, Gorgias realiza un esfuerzo retórico-filosófico para defender el carácter incomunicable de la realidad. Así, el nihilismo ontológico que aparentemente destila el ensayo (lo cual sancionaría un posicionamiento agnóstico de Gorgias) se interpreta, en los estudios de Curd, Woodruff y Ioli ${ }^{13}$, como un alegato vehemente contra los postulados de la escuela eleata y el dogmatismo inherente

${ }^{111}$ Amén de los estudios clásicos, nos ceñimos a publicaciones entre nosotros recientes. Con carácter general, López Eire 1997; 2000; Iglesias Zoido 2000; Cortés Gabaudan 2005; Ramón Palerm 2006.

112 Por razones distributivas, considerando los testimonios formalmente transmitidos y atendiendo al carácter predominantemente incisivo de sus composiciones oratorias, hemos optado por abordar los datos pertinentes de Gorgias y de Antifonte en este apartado de nuestra actualización.

${ }^{113}$ Woodruff 1999: 305-306; Curd 2006; Ioli 2009: 356. 
a las pretensiones absolutistas de las ontologías precedentes. Por cuanto atañe al Epitafio, contamos con una incisiva apología: Durán López salvaguarda la religiosidad tradicional de nuestro orador y aprecia en ciertas manifestaciones del discurso las maneras de una piedad singularmente personal ${ }^{114}$. La tesis de Durán López, que se extiende al conjunto de la producción gorgiana, se fundamenta aquí en la acumulación de términos rotundamente fervorosos hacia

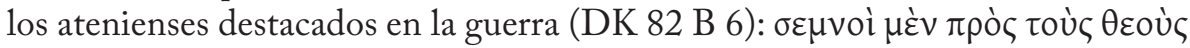

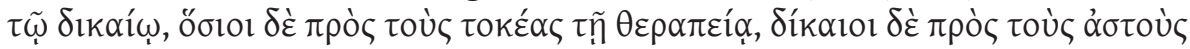

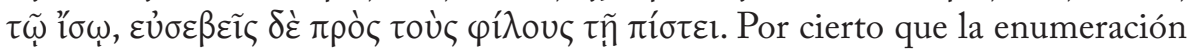

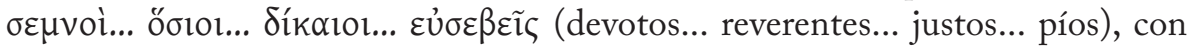
una estudiada formalización de paralelismos sintácticos, es sin duda relevante; y conscientemente hiperbólica en el texto transmitido por Dionisio de Heraclea a principios del siglo III a.C ${ }^{115}$. Con todo, creemos que la 'ley' o 'convención normativa' del género (la cual consta explícita, como veremos, en el Encomio de Helena) se antoja dominante: no sorprenderá el énfasis que un oradorsofista oriundo de Leontinos, meteco en Atenas, establezca para subrayar el cariz indeclinablemente patriota -donde las virtudes piadosas desempeñan una función cardinal- de cuantos ofrendaron su vida a la causa común de la polis. En consecuencia, procede ajustarnos a los discursos epidíctico-judiciales efectiva y completamente legados. Se trata de sendas piezas panegíricas donde el orador despliega la versatilidad de sus aptitudes formales mediante un esquema puntillosamente logrado ${ }^{116}$. Así, en la Defensa de Palamedes asistimos a un discurso apologético en que el personaje clásico (enemigo íntimo y proverbial de Odiseo) rehúsa la imputación de connivencia con los troyanos. Como indica Durán López, las únicas manifestaciones de importancia para nuestra cuestión que refiere Palamedes son compatibles con la religión cívica. Sin embargo, la solemnidad sentenciosa de las palabras que aduce el héroe resultan asimismo coherentes con tópicos recurrentes en el género (los cuales maneja Gorgias con pericia cuidada en defensa de Palamedes): el traidor atenta contra la ley,

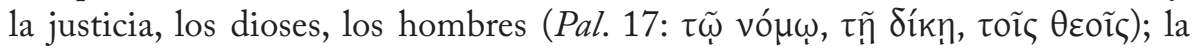
deslealtad con Grecia es vileza hacia uno mismo, los padres, los prójimos, los

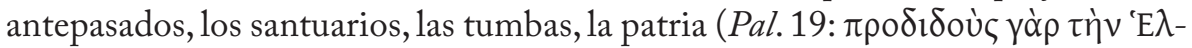

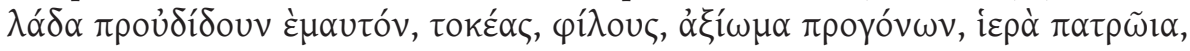

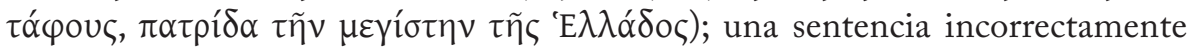

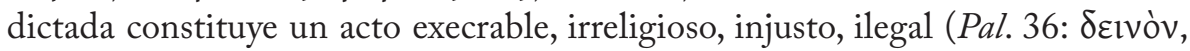

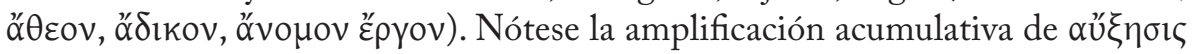
inherente al género epidíctico.

${ }^{114}$ Durán López 2011: 307-313.

115 Cf. Melero 1996: 194 n. 112.

${ }^{116} \mathrm{El}$ perfil morfológico de los discursos se encuentra convenientemente desarrollado en Melero 1996: 200-223. 
Con todo, el Encomio de Helena se erige en la pieza gorgiana de mayor aprecio, paradigma del discurso demostrativo. La inventio es conocida: Helena, la 'mala mujer' por antonomasia en el imaginario colectivo de Grecia, responsable tradicional de la 'Guerra de Troya' por su adulterio de complicidad con Paris-Alejandro, debe ser formal y moralmente exculpada de esa infamia. En efecto, cometiera su acción movida por el azar, por la violencia, por la seducción por la palabra, por el ímpetu del amor, Helena merece absolución en cualquier contingencia. Al respecto, de nuevo Durán López ha incidido en los aspectos divinales que emanan del texto, en la idea de que la obrita se compadece con una visión primaria de la religión tradiciona ${ }^{117}$. Es verdad que, como defiende la autora, la primera hipótesis que maneja Gorgias (la fuerza motora del azar en el proceso) se ve acompañada en modo coordinado por la presencia de los dioses y de la necesidad (Hel. 6: Túxn

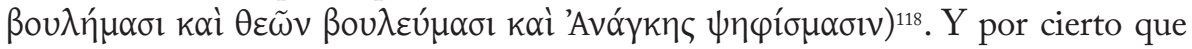
la relación e interpenetración de los dioses con fuerzas impersonales como las expuestas se halla convencionalmente acrisolada ${ }^{119}$. Ello explica que Durán López conecte este pasaje con la síntesis conclusiva del orador y la apelación de este a la

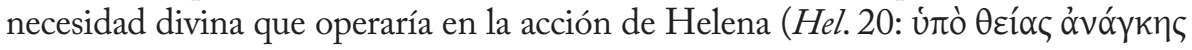
àv $\alpha$ $\kappa \alpha \sigma \theta \varepsilon \tilde{i} \sigma \alpha)$, lo que unido a la presencia del sintagma inmediatamente anterior

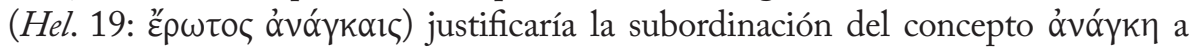
las deidades ${ }^{120}$. Aceptando la coherencia expositiva, creemos que el argumento es matizable. Primeramente conviene subrayar que, en la celebrada reflexión de Gorgias sobre el poder persuasivo y mágico de la palabra ${ }^{121}$, el orador somete la

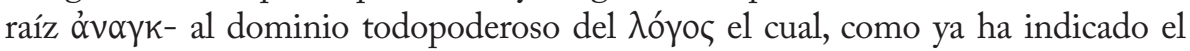
orador previa y expresamente, es un soberano firme, capaz de obras absolutamente

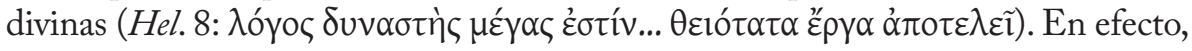
el pasaje ahora pertinente describe, en estilo de redundancia antitético-repetitiva,

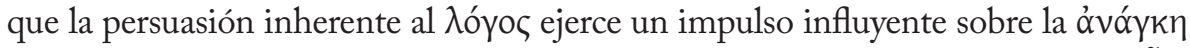

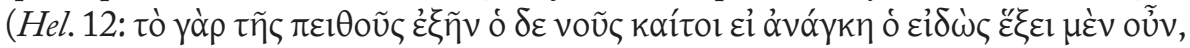

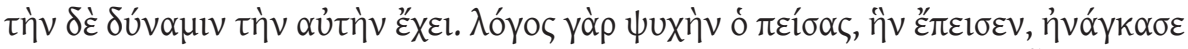

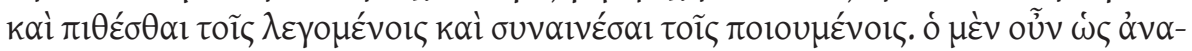

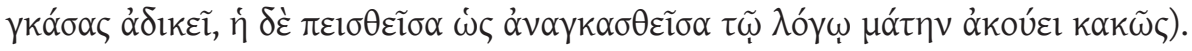
Como Innes ha demostrado fehacientemente, Gorgias concede una importancia

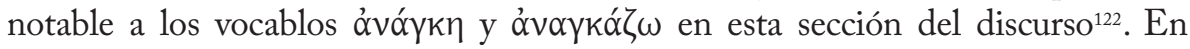
síntesis: si la fuerza seductora de la palabra domeña con actos sumamente divinos

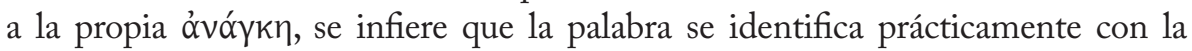

\footnotetext{
${ }^{117}$ Durán López 2011: 280-282.

${ }^{118}$ Reproducimos el texto con arreglo a la normalización que consta en DK 82 B 11.

119 Melero 1996: 204 n. 138.

${ }^{120}$ Durán López 2011: 283.

${ }^{121}$ Cf. Caramés 2010.

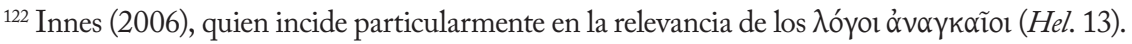


propia deidad. Por consiguiente, he aquí una doctrina de Gorgias manifiestamente innovadora que afecta a los ámbitos retórico, político, judicial y religioso.

Asimismo, debemos atender al epílogo que corona el discurso mediante una declaración programática de método. El caso es que Gorgias declara su atención a la ley normativa (acaso ley sancionada del propio género) que se impuso al principio de la pieza y confiesa sin ambages su anhelo conseguido: la redacción de un encomio de Helena que, por añadidura, se trata de un divertimento personal

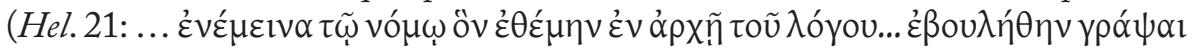

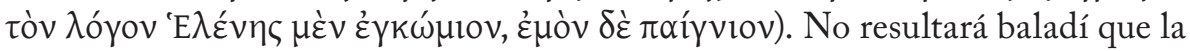
voz $\pi \alpha$ íyviov concluya el discurso y revele, de esta guisa, el cometido prioritario de la pieza ${ }^{123}$ : un experimento discursivo a favor de esa técnica retórico-oratoria, exponencialmente depurada, que habría de resultar capital en el desarrollo de la prosa artística.

\subsection{Antifonte}

Si hay un factor que sorprende al estudioso de la Antigüedad Clásica es la personalidad nebulosa y polifacética del presente autor, el cual ha concitado debates de envergadura en la crítica científica. Resulta incontrovertible que la llamada cuestión antifontea ha concentrado una polémica prolijamente acerada en torno a la identidad de un sujeto dotado, como refiere encendidamente Tucídides (8. 68. 1), de esa condición portentosa para el arte de la oratoria. Así ha ocurrido, ya que la tradición literaria sobre Antifonte nos ha legado un corpus de factura multidisciplinar, proclive esencialmente a la composición de discursos en su condición de logógrafo, a la redacción de piezas oratorias con interés didácticodoctrinal y a la elaboración de trataditos ensayísticos con un interés cultural, ideológico. Esta circunstancia y la relevancia pretendida de ciertos testimonios tardíos (en particular de Hermógenes, gramático del siglo III d.C.) ha conformado la tradición de una querella a nuestro juicio estéril: ¿Hubo uno o varios Antifontes? En la actualidad las posiciones de los estudiosos vienen abocando -hecha alguna excepción de pertinacia- al carácter unitario de un individuo cuya catalogación intelectual resulta esquiva a planteamientos unidireccionales. Con todo, el análisis combinado de la forma y de su exposición encaja en la actitud literaria de un autor provocativamente desdoblado como rétor, maestro de retórica, ensayista sagaz ${ }^{124}$.

${ }^{123}$ Makin (2013) comenta las posibilidades interpretativas del colofón al discurso y la intención que destila el término $\pi \alpha$ ífvııv, acaso de índole expresivo-impresiva para beneficio del lector u oyente del discurso. A nuestro parecer, prima la función de autoridad que reclama Gorgias en la consolidación de un género.

${ }_{124}$ Sobre la denominada cuestión antifontea, puede verificarse la justificación del carácter unitario en la actualización crítica de Ramón Palerm (1996a). Cf. asimismo Gagarin 1990; 2002; Ortolá 2003 (con subrayado de los aspectos lingüísticos). La hipótesis analítica prácticamente ha quedado relegada a la defensa de Pendrick 1993; 2002: 1-26. 
A decir verdad, los escasos fragmentos de sus composiciones ensayísticas quedan estrictamente recogidos en el tratado Sobre la verdad, ya que Sobre la concordia es realmente un compendio de sentencias donde Antifonte (oriundo de Ramnunte, demo ático) reflexiona en un tono suavemente hedonista -parejo al que asoma en la lírica grecoarcaica- acerca de los placeres y sinsabores de la existencia. Debemos apostillar que conservamos estos pasajes merced a la tradición indirecta, debida en medida notabilísima al erudito Juan Estobeo quien, en su Florilegio, cultivala selección de testimonios antiguos sometidos a un proceso de severidad didáctico-moralista ${ }^{125}$ : precisamente por ello la conexión de los pasajes con el criterio ideológico-doctrinal o (ir)religioso de Antifonte se antoja sobremanera endeble ${ }^{126}$. Y, por la misma razón inherente a la parquedad genuina de las fuentes, juzgamos infundada la tesis que persigue detectar en Antifonte al individualista paradigmático, arquetipo de una ética irrefutablemente libertaria ${ }^{127}$. Por otro lado, los magros fragmentos papiráceos que conservamos en Sobre la verdad han merecido la atención pormenorizada de los especialistas desde una óptica ideológica pero a nuestro parecer no translucen aspectos de relevancia en el mundo religioso de Antifonte ${ }^{128}$. Prima aquí la crítica al

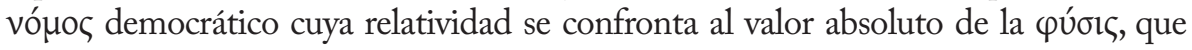
nuestro autor encumbra tenazmente (DK 87 B 44B) ${ }^{129}$. Esta condición se compadece con la divisa oligárquica, no exenta de pragmatismo, propia de Antifonte ${ }^{130}$. Amén de ello, la igualdad en la biología humana que parece inferirse de la sentencia antifontea ("absolutamente todos hemos nacido por naturaleza en pie de igualdad para ser

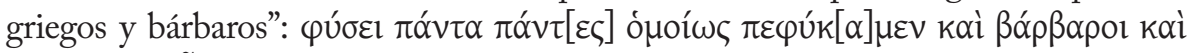

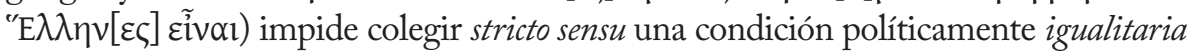

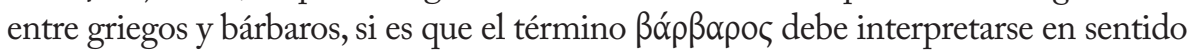
convencional y no, como perspicazmente sugiere Labriola, referido a un entramado de oposiciones en el seno de la población griega ('ateniense / no ateniense', 'hombre libre / esclavo,' 'ciudadano / no ciudadano') ${ }^{131}$.

Con todo, lo cierto es que el debate antinómico entre un Antifonte moralista o inmoralista (ligado sin duda a la consideración de un sujeto disciplinadamente opaco y ambiguo en la exposición argumental ${ }^{132}$ ) subyace en la reflexión germinal de los estudiosos ${ }^{133}$, lo cual nos invita directamente a examinar la

${ }^{125}$ Labriola 1992: 30-36 y 134-136.

${ }^{126}$ Solana 2012: 354 n. 35.

${ }^{127}$ El valedor capital de esta tesis es Onfray 2007.

${ }^{128}$ No obstante, cf. Durán López 2011: 329-338.

${ }^{129}$ Decleva Caizzi 2008: 327; Veneciano 2008.

${ }^{130}$ Cf. Edwards 2004.

${ }^{131}$ Labriola 1992: 68-75.

${ }^{132}$ Cf. Gagarin 2002: 92.

${ }^{133}$ Este factor encaja bien con el carácter antilógico que jalona la obra de nuestro autor, cuya estudiada $\sigma \omega \varphi \rho \circ \sigma u ́ v \eta$ estructural ha concitado justamente la admiración de la crítica. Cf. Labriola 1992: 76-78. 
conformación que el de Ramnunte efectúa sobre las categorías religiosas e irreligiosas en el ámbito de su práctica oratoria. $\mathrm{Al}$ cabo, constituye motivo de estupor científico que Antifonte, quien exhibe la mayor proporción de congeries sobre terminología (ir)religiosa en su producción literaria, no haya merecido un ensayo pormenorizadamente atento sobre la tensión 'religión / irreligiosidad' que vertebra sus piezas discursivas, las cuales subsumen un mundo de fascinación al servicio del magisterio y de la actividad jurídico-política. En tal sentido, debiéramos remontarnos al estudio deliciosamente veterano que consagró Decleva Caizzi, con seguridad la mejor especialista en la obra propedéuticooratoria de Antifonte ${ }^{134}$. No es momento ahora de extendernos en las virtudes del ensayo introductorio y de la edición crítica que nos ha legado la autora, pero debe subrayarse la interacción, exquisitamente comentada, de los paradigmas (ir) religiosos que Antifonte maneja: este factor se percibe particularmente en Las Tetralogias mediante la conexión de las especies jurídico-religiosas o, por mejor decir, la manipulación de los conceptos (ir)religiosos conforme al pensamiento sofístico y a la defensa del ideario propio merced a sutilezas de hechizo expositivo. En efecto, Decleva Caizzi explica admirablemente que, en el conglomerado léxico del magisterio jurídico-religioso que profesa Antifonte, los términos

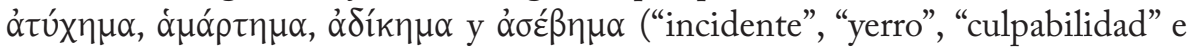
"impiedad") se conjugan de forma inextricablemente magistral para configurar una red de conceptos que persigue, en apariencia, atentar dialécticamente a una norma religiosa cuya validez se pretendía absoluta hasta el siglo $\mathrm{V}$ a.C ${ }^{135}$. Habida cuenta el esfuerzo inteligentemente persuasivo de la autora, debemos lamentar -como queda dicho- la inexistencia de contribuciones recientes que hayan ahondado en el problema mediante una formalización global del vocabulario (ir) religioso que abarca la obra oratoria de Antifonte en su dimensión más capaz. No obstante, es justo reseñar la reciente y sugestiva monografía de Leite ${ }^{136}$. La

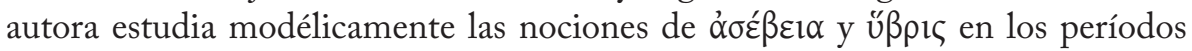
arcaico y clásico de Grecia para determinar la incidencia de las mismas en el corpus demosténico. Como era de esperar, las conclusiones demuestran que los conceptos implicados se manejan para desacreditar la figura del oponente en el acto discursivo y predisponer a los jueces para la causa propia en detrimento de las posiciones ajenas. Debe subrayarse que, en el curso de su indagación, Leite comente incidentalmente el uso de los términos citados por parte de Antifonte,

134 Decleva Caizzi 1969, especialmente 17-41. Nos permitimos glosar los aspectos fundamentales del estudio considerando que, por añadidura, el volumen no consta en la recopilación bibliográfica debida a Winiarczyk 1994.

${ }_{135}$ Decleva Caizzi 1969: 68-70. En una línea de exégesis pareja, cf. Vegetti 2008: 275, quien afirma expresamente que las cuestiones de responsabilidad y de culpabilidad se debaten "both in a moral and religious context... and in the legal sphere".

${ }^{136}$ Leite 2014a: 151-182. 
el rétor más antiguo del canon sancionado y pionero de los logógrafos judiciales. Asimismo, brilla el estudio de los elementos (ir)religiosos que estructuran las antilogías presentes en Las Tetralogías, con especial referencia al problema de la contaminación religiosa ( $\mu$ í $\sigma \tilde{\mu} \alpha$, fenómeno arcaizante y popular en la conciencia colectiva) y a la valoración de terminología complementaria funcionalmente significativa, como el adjetivo óvóolos y los elementos gramaticales anejos al tema $\alpha \sigma \varepsilon \beta-137$. Sin embargo, es obvia la carencia de un estudio que aborde conjuntamente las implicaciones jurídico-político-religiosas que posibilitan los étimos de relevancia indefectible. $Y$ es que Antifonte incluye con fruición vocablos que merecen una atención esmerada. A título ilustrativo, repárese en

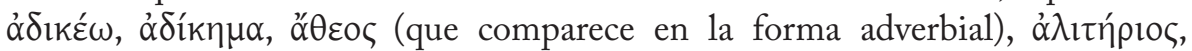

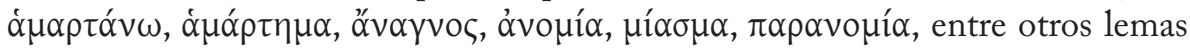
de nota los cuales vertebran, con exquisito criterio distributivo, las composiciones oratorias de Antifonte. Por lo demás, los trabajos de mayor enjundia sobre nuestro logógrafo-sofista vienen insistiendo en las características retórico-legales de la argumentación antifontea, con Gagarin como máximo exponente de esta orientación metodológica ${ }^{138}$.

\subsection{Andócides}

El caso de Andócides muestra ejemplarmente el impulso que, en los últimos decenios, ha cobrado el interés renovado de la comunidad científica por encajar los problemas de índole (ir)religiosa, con todas sus vertientes, en la tensión ideológico-política que afecta a las postrimerías de la Atenas Clásica. Habida cuenta la sucinta -y significativa- producción del oligarca ateniense que la tradición literaria nos ha legado, ajustándonos asimismo a la prosopografía cuasinovelesca de Andócides, resulta de todo punto comprensible que su pieza oratoria Sobre los misterios (de cuya morfología técnica, en verdad comprometida, prescindimos aquí) haya concitado el favor de la crítica histórico-filológica en relación con el tema que nos ocupa. En efecto, la implicación directa o indirecta, real o fingida, de Andócides en la 'Profanación de los Misterios' y en la 'Mutilación de los Hermes' resultaron factores de extraordinaria importancia ya en la propia época (ahí está el libelo discursivo Contra Andócides, del PseudoLisias); y la portentosa edición comentada que MacDowell consagró a Sobre los misterios en los años sesenta del siglo pasado viene justificando la proliferación de una controversia acerada sobre las motivaciones de índole judicial y religiosopolítica que el discurso andocideo destila, con implicaciones relevantes acerca

${ }^{137}$ Muy recientemente, Naiden (2016) ha espigado en las relaciones susceptibles de

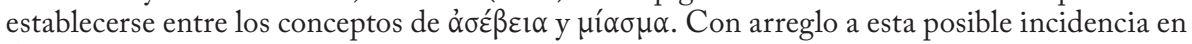
Antifonte, cf. Naiden 2016: 66-67.

138 Especialmente Gagarin 2002, que constituye una obra de referencia y consulta indispensable en los estudios antifonteos. 
de ese conflicto global que arrostra la Atenas del siglo V a.C. en el entramado de la vida pública ${ }^{139}$; máxime atendiendo al carácter privadísimo e íntimamente personal del discurso, puesto que Andócides nunca se reveló -en lo que a nosotros alcanza- como un logógrafo profesional al servicio de causas ajenas.

Así las cosas, el volumen de Furley constituye un hito de paradigma en la crítica especializada acerca de nuestro discurso, la prosopografía de Andócides y los factores de índole político-religiosa que laten en la composición ${ }^{140}$; y ello con particular incidencia en la valoración de los aspectos (ir)religiosos que presenta Sobre los misterios, a los cuales no resulta ajena la manipulación de las prácticas rituales y religiosas por parte de las clases dirigentes. Para ser más precisos, Furley comenta con pormenores tres aspectos de importancia capital. En primer lugar, el discurso de Andócides, como ocurre también en la obra de Tucídides, deslinda las intervenciones en cuestión, a saber, la profanación o parodia de los 'Misterios Sagrados' (razón básica del juicio por impiedad que, enmascarado técnicamente mediante una $\varepsilon^{\prime} v \delta \varepsilon l \xi 1 \varsigma$, afronta Andócides en su apología) y la 'Mutilación de los Hermes'. En tal sentido, Furley se adhiere a la disociación de ambos sucesos y, admitiendo el valor político-religioso a ellos inherente, juzga prevalente el factor religioso para la profanación mistérica y el factor político para la amputación de los Hermes ${ }^{141}$. En segundo lugar, los mandatarios atenienses manipulaban los signos religiosos por razones de rentabilidad política, con el propósito de obtener el favor popular pro domo sua; y, al respecto, la defensa de Andócides se orienta a revelar la transgresión consciente de las normas religiosas que ejercen los garantes oficiales de las mismas ${ }^{142}$. En tercer lugar, Furley se detiene modélicamente en la explicación técnica de ciertos términos irreligiosos cuya especificidad semántica resultaba adecuada en el conjunto de la oratoria judicial

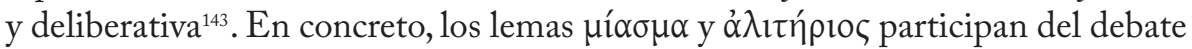
político-religioso. El primero de ellos, $\mu$ í $\sigma \sigma \alpha \alpha$ (que resulta operativo en el caso de Antifonte), se halla ausente en el curso del relato andocideo. Sin embargo, el término $\alpha \lambda_{\imath \tau}$ ṕpı Andócides, ya que este utiliza el vocablo con el propósito de menoscabar la pietas religiosa de Calias, íntimo enemigo de nuestro orador y objetivo esencial de la argumentación probatoria que Andócides esgrime para defender su causa. En efecto, el sujeto ờıı́́pı̊ৎ adopta esta condición por haber malquistado a

${ }^{139}$ MacDowell 1962.

${ }^{140}$ Furley 1996.

${ }^{141}$ Furley 1996: 41-48. Cf. asimismo Leão (2004: 209-218), quien subraya las circunstancias irreligiosas de los actos: el carácter impío que conllevaba la 'Mutilación de los Hermes' y la condición particularmente sacrílega, aneja a la 'Profanación de los Misterios'.

${ }^{142}$ Furley 1996: 93-106. Por añadidura, Edwards (2008) defiende la mención pertinaz a los dioses, en la oratoria ática del siglo $\mathrm{V}$ a.C., como indicio de complicidad ante una población que observa la presencia de las divinidades ligada persistentemente a la realidad cotidiana.

${ }^{143}$ Furley 1996: 109-110. 
los dioses y, consiguientemente, sobrellevar una vida mísera, despreciado de las potencias divinas. Como ya advertimos en el caso de Antifonte, se antoja atractiva la circunstancia de que sean preferentemente oligarcas quienes, en el manejo de causas propias o ajenas, apelen a conceptos (ir)religiosos de raigambre en la cultura griega y coyunturalmente manipulables en el entramado jurídicopolítico-religioso.

Al compás de la excelente monografía de Furley, nos hemos pronunciado sobre la fusión de ciertos elementos indefectibles en la obra de Andócides: la realidad político-religiosa, los aspectos jurídicos ${ }^{144}$, la condición oligárquica del autor.A decirverdad, con anterioridad a la publicación de Furley, aparecieron sendas aportaciones (distintas en intención y fortuna) que se centran en la perspectiva mencionada. De este modo, Mactoux expone una brillante contribución de factura eminentemente terminológica donde la investigadora revisa con tino el campo léxico-semántico de naturaleza religiosa (donde los conceptos y lemas oportunos del par 'piedad / impiedad' quedan convenientemente subrayados), sin merma de las cuestiones político-jurídicas concernientes al caso, en la idea de que la parte acusadora persigue una politización de la faceta jurídico-religiosa ${ }^{145}$. Felizmente Mactoux añade la cuestión inherente al parentesco del orador, un tópico de recurrencia (insistamos en el caso de Antifonte) que pretende persuadir a los jueces sobre la nobleza genuina de las acciones desplegadas y de la vida misma que defiende Andócides con ardor ${ }^{146}$. El caso es que, como quiere Mactoux, todos los niveles citados se incardinarían en el discurso apologético de Andócides. Por su parte Missiou, cuya tesis se centra aquí en el discurso Sobre la paz con los lacedemonios, incide sobremanera en el linaje oligarca de Andócides, al punto de vincular lo que juzgamos un mero tópico de efectismo (la insistencia en la nobleza y el parentesco del personaje) a una defensa sutilmente encubierta de las clases altas, contingencia que hallaría su reflejo en el discurso mencionado que la autora analiza con pormenor ${ }^{147}$. Lo cierto es que, como indica sugestivamente Ober con su recensión al trabajo de Missiou, el funambulismo de Andócides

${ }^{144}$ Harris - Canevaro (2012) han estudiado y analizado con escepticismo la fiabilidad de la documentación legal que consta en Sobre los misterios.

145 Mactoux 1989. Glosamos el trabajo, aparte la importancia intrínseca del mismo, por hallarse exento del inventario que facilita Winiarczyk 1994. Por lo demás Furley omite la contribución de Mactoux, como indica Pirenne-Delforge (1998: 401) en su reseña crítica al libro de Furley (discrepante sobre ciertos puntos metodológicos del volumen reseñado).

${ }^{146}$ Igualmente, Strauss (1993) incide en la utilización categórica del parentesco y de

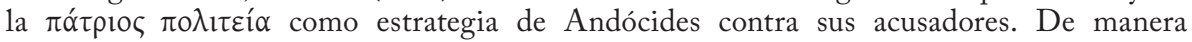
complementaria, Schubert (2013) ha profundizado en el sello de la $\varphi \imath \lambda i ́ \alpha$ que conforma la composición. Como es lógico, considerando la inexistencia profesionalizada de un cuerpo judicial y la naturaleza electiva de los jueces en la democracia ateniense, estos podían ser

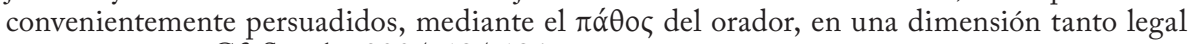
cuanto retórica. Cf. Sancho 2005: 185-186.

${ }^{147}$ Missiou 1992. 
en el marco de una democracia conformada sobre la restitución del 403 a.C. dificultaba (si no imposibilitaba factualmente, apostillamos) la defensa de los principios oligárquicos ${ }^{148}$. Y es que, como era de esperar, el orador podía enfocar su discurso en términos persuasivos pero no subversivos.

El caso es que, a tenor de la bibliografía más acreditada sobre Andócides, la tensión 'piedad / impiedad' que jalona Sobre los misterios y el problema acuciante de la crisis religiosa que afecta a la Atenas Clásica nos han deparado, ya de pleno en el siglo XXI, varios estudios que destacamos por su originalidad y rigor. En un trabajo singularmente incisivo, Todd sugiere la posibilidad de que el escándalo irreligioso que supuso la 'Mutilación de los Hermes' condujera a interpretar paralelamente, en el imaginario popular, la 'Profanación de los Misterios' (cuando, habida cuenta el secretismo inherente a los mismos, resultaba delicado corroborar el grado de impiedad existente en la empresa) ${ }^{149}$. Sucede que Todd juzga irrelevante la implicación o culpabilidad de Andócides en ambas acciones, mientras que subraya el conocimiento detallado que el oligarca pudo obtener de sus informadores con el propósito de soslayar ciertos pormenores ominosos en su discurso apologético. En última instancia, aclarado el hecho de que la decapitación de los Hermes se produjo con alevosía y nocturnidad de luna nueva, se revela improbable conocer si la maniobra correspondió a facciones oligarcas, antidemocráticas, o a grupúsculos sectarios, ultrarreligiosos, que no calcularon las consecuencias de su cometido ${ }^{150}$.

Meritorio es también el análisis de Carawan, cuya tesis principal reposa en el convencimiento de que la condición piadosa consustancial a la trayectoria vital de Andócides -base argumentativa en el discurso de nuestro orador-, reputada frecuentemente como pura mistificación de circunstancias, rebasa la frontera religiosa para enmarcar y conectarse con la realidad legal de amnistía que se legisla en el 403 a.C. De este modo, Andócides liga con inteligencia el sentimiento religioso de que blasona con las circunstancias jurídicas anejas al momento histórico ${ }^{151}$.

Con todo, es Gagné quien, con un artículo de innovación sugerente y provocativa, ha expuesto recientemente un panorama de ideas controvertibles sobre la utilización de la (ir)religiosidad, la (im)piedad, el estatus de estos conceptos en la Atenas de finales del siglo V a.C y el manejo que efectúa Andócides de las mencionadas categorías ${ }^{152}$. Las propuestas fundamentales del autor, mediante la revisión crítica de las teorías y aportaciones más consolidadas, son las siguientes:

\footnotetext{
148 Ober 1994.

${ }^{149}$ Todd 2004.

${ }^{150}$ En palabras textuales de Todd que coronan su artículo (2004: 97), “The Mutilation of the Herms: conspiracy or cock-up?".

${ }^{151}$ Carawan 2004.

152 Gagné 2009.
} 
a) Pese a la insistencia de las fuentes literarias y las conjeturas expuestas, no existen testimonios documentales, en el siglo $\mathrm{V}$ a.C., que prueben la existencia de juicios por delitos de opinión en el Ática. b) La cuestión de la crisis religiosa en la Atenas finisecular constituye, en rigor, un falso problema, dado que se trata de una contingencia que caracteriza secularmente a la historia de la humanidad. c) Las causas judiciales ligadas a la contravención de los misterios eleusinos se erigen en la única excepción contrastable al clima de libertad religiosa en Atenas durante el período clásico. d) En consecuencia, ante la carencia de jurisprudencia

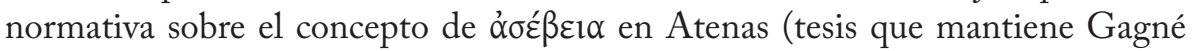
con la salvedad relativa a los Misterios eleusinos), las estrategias que adoptan Andócides y sus acusadores en Sobre los misterios se orientan a esgrimir la retórica de la (ir)religiosidad para sus respectivas causas, donde el efectismo dramático desempeña un papel de magnitud persuasiva. Sin duda las reflexiones de Gagné resultan seductoras y, en buena medida, congruentes con la realidad de los hechos, puesto que nos movemos en ámbitos de imprecisión documental. Compartimos esencialmente el carácter retoricista que observan las categorías (ir)religiosas en la argumentación agonal de los litigantes. Por añadidura, es cierta la condición singular de los misterios eleusinos desde el momento en que se trataba, por excelencia, de una liturgia estrictamente ceremoniosa en el Ática. Sin embargo, discrepamos de esa exposición reduccionista sobre el tenor de la crisis religiosa que experimenta la Atenas de época clásica. Por mencionar tan solo datos de índole terminológica que objetan al planteamiento de Gagné: lemas de irrefutable conciencia irreligiosa comparecen por vez primera en el siglo $\mathrm{V}$ a.C. y en la literatura griega. Ahí están, citando de manera restrictiva los nombres

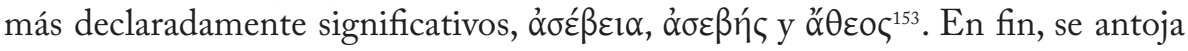
innecesario redundar en tautologías puesto que la lengua refleja las condiciones y los conflictos culturales de una época. Amén de ello y pese a la tenacidad expositiva de Gagné, es harto improbable que la práctica explícita del ateísmo constituyera una life option, por indicarlo con la expresión certera de Bremmer ${ }^{154}$.

\section{LA HISTORIOGRAFÍA}

En el ámbito de la historiografía griega, las figuras señeras de Heródoto y de Tucídides han merecido la atención que cabía esperar, lógicamente de modo distinguido habida cuenta la orientación metodológica y la concepción marcadamente dispar del enfoque respectivamente crítico sobre el esquema religioso

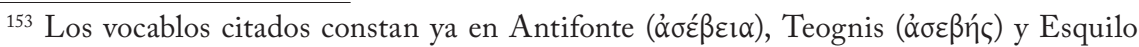

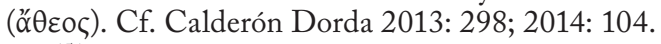

${ }^{154}$ Bremmer 1982: 51. Por lo demás, resulta seguramente ilustrativo el pasaje del doxógrafo Aecio 1. 7. 2 (DK 88 B 25), donde se filtra la interpretación de que algunos intelectuales soslayaban su orientación irreligiosa "por miedo al Areópago" (cf. Melero 1996: 429). 
de la época. Por consiguiente, las valoraciones recientes de los estudiosos acerca de nuestros historiadores reflejan adecuadamente la dificultad de operar con criterios unidireccionales ${ }^{155}$.

\subsection{Heródoto}

Independientemente de las vías analíticas que los autores modernos han explorado sobre el modelo herodoteo, existe unanimidad exegética en un punto de partida inicial: la respuesta del Halicarnaseo a los problemas de índole religiosa se muestra renuente a una interpretación de signo doctrinario. De hecho, los especialistas más avezados han incidido en la coexistencia de niveles -a menudo desconcertante- que abarcan una graduación sensible desde la aparente aceptación, resignadamente asumida, de las manifestaciones divinas hasta la sutileza de críticas incidentales sobre el paradigma religioso. Ello explica que el profesor Masaracchia hable de la intrincada dialéctica inherente a las posiciones de Heródoto, en quien observa los trazos de un proceso de racionalización y desmitologización sobre la realidad existencial ${ }^{156}$. Por su parte, Harrison enfatiza la paradójica ligazón de un escepticismo doctrinal con la experiencia de ese conservadurismo que subyace a la tradición heredada y penetrante en la formación religiosa del historiador; y ello puede verificarse en la aquiescencia ocasional del sistema greco-arcaico, en la atención cuidada a los adivinos y a los intérpretes de oráculos, en la misma exhibición del relato oracular, en el castigo vindicativo que, como sucede con Cambises, recae inexorablemente sobre los sujetos de úßpıৎ impía. Efectivamente, Harrison señala el contraste de estos elementos con ciertas manifestaciones a propósito de la percepción que los seres humanos obtienen de la divinidad ${ }^{157}$. En tal sentido, recuérdese el celebrado axioma en el cual expone Heródoto su creencia de que todos los hombres tienen similares nociones sobre los dioses (2.3.2). El caso es que Harrison equipara la opinión de Heródoto con el escepticismo religioso de Protágoras. De manera más cuidadamente ecléctica, Mikalson sostiene que las contradicciones anejas al modelo historiográfico de Heródoto (también por cuanto afecta a las ideas religiosas) se explican esencialmente merced al acervo de las fuentes -de fiabilidad medida y compleja- que maneja el de Halicarnaso ${ }^{158}$. Para

${ }^{155}$ En cualquier circunstancia, por su interés y provecho para estudios léxico-semánticos de toda índole, deben subrayarse las meritorias 'concordancias lematizadas', sobre Heródoto y Tucídides, debidas a Schrader 1996; 1998.

156 Masaracchia 1998: 287-288. No obstante la publicación primera de la contribución en 1988, hemos juzgado relevante la inclusión del estudio dado el inventario de compilación que, junto a otras aportaciones del profesor Masaracchia, fue editado con posterioridad. Cf. asimismo Schrader 1997: 88-90.

${ }^{157}$ Harrison 2000, especialmente 243-246.

${ }^{158}$ Mikalson 2003: 136-195. 
ser más precisos, los estudiosos inciden en una proyección de la religiosidad y del factor numinoso permeables a la aceptación, por parte de Heródoto, del proceso ritual pero yermos de un hecho que observamos frecuentemente en la tragedia ${ }^{159}$ : la participación activa de los dioses en las empresas de los hombres, la cual adopta una presencia restringida en la Historia herodotea. Correlativamente, cobra un valor añadido la (ir)responsabilidad humana en el desarrollo de los acontecimientos ${ }^{160}$. Es cierto que, como Bowden y Flower han

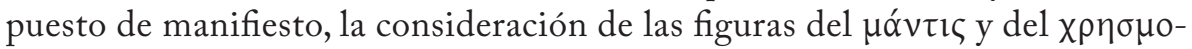
$\lambda o ́ \gamma o \zeta$ ofrece una visión básicamente ponderativa en el relato de Heródoto ${ }^{161}$, si bien el tratamiento de ciertos episodios oraculares parece cuestionar la fiabilidad de los exegetas profesionales o alejarse de una pietas convencional, aceptable en el ideario religioso de un ciudadano común. Por cierto que, entre nosotros, Sánchez Mañas ha consagrado un estudio de índole estructural a la tipología de los oráculos en Heródoto y, de conformidad con su análisis, detectamos la existencia de algunos episodios significativos ${ }^{162}$. No entraremos en pormenores sobre el celebérrimo oráculo del 'Muro de Madera' (7. 141143), donde la respuesta oracular, alusiva a un muro de madera y a Salamina, recibe una interpretación de los $\chi \rho \eta \sigma \mu о \lambda o ́ \gamma o r$ que colisiona con la inferencia de Temístocles, quien dispone aprestar las naves (identificadas por el estadista con el muro de madera) a fin de presentar batalla en Salamina: triunfa la propuesta de Temístocles con el resultado consabido y la rentabilización propagandística para los intereses de Atenas ${ }^{163}$. En realidad, un segundo episodio oracular puede cobrar relevancia añadida: nos referimos a cierto relato sito en el marco del lógos egipcio, relato ilustrativo sobre la consulta que los pelasgos efectúan en el santuario de Dodona con arreglo a los nombres de los dioses a quienes honran (2.52). Como ha sido convenientemente advertido ${ }^{164}$, Dodona -aquí centro y fuente de respuesta oracular- era posiblemente la sede religiosa más antigua en el mundo griego, de importancia equitativa al santuario délfico. Pues bien, la especial relevancia del pasaje radica en una circunstancia singular: la sede comunica a los pelasgos que los nombres de los dioses a quienes estos tributan honores proceden de los egipcios, con la particularidad de que los pelasgos, a su vez, transfieren los oủvó $\mu \alpha \tau \alpha$ divinales a los griegos. Efectivamente, se antoja significativo $-\mathrm{y}$ tal vez socialmente

159 La crítica especializada viene insistiendo en el factor de la ritualización como procedimiento inherente al vademécum religioso de Heródoto. Cf. Gould 1994.

${ }^{160}$ Harrison 2000: 223-242.

${ }^{161}$ Bowden 2003: 264-265; Flower 2008: 16. Con todo, Mikalson (2003: 246) admite que Heródoto se hallaba familiarizado con los círculos de escepticismo en relación con las prácticas proféticas.

162 Sánchez Mañas 2015.

${ }^{163}$ Cf. Bowden 2003: 272-274; Sánchez Mañas 2015: 207-212.

${ }^{164}$ Flower 2008: 242; Sánchez Mañas 2015: 311 
lacerante para un concepto tradicional de $\varepsilon \dot{\sigma} \sigma \varepsilon ́ \beta \varepsilon l \alpha-$ que Dodona, santuario griego por excelencia, confirme solemnemente que los nombres de los dioses correspondientes no son genuinamente griegos ${ }^{165}$.

En realidad, Heródoto incluye -sin la menor inocencia, creemos- el episodio oracular que hemos seleccionado en un marco vertebrador de notable comparación funcional: la religiosidad del pueblo egipcio explica incipientemente la arquitectura religiosa de la cual se han dotado los griegos. He aquí la fuerza de los datos que debieron de resultar, cuando menos, desconcertantes en la Atenas Clásica y habrían de justificar posteriormente una literatura historiográfica de naturaleza debeladora, sin merma de censuras sobre la irreligiosidad del Halicarnaseo ${ }^{166}$. De manera representativa, valgan los siguientes testimonios. Heródoto expone: que al decir de los sacerdotes lugareños, los egipcios fueron precursores en adoptar advocaciones para doce dioses, así como instituir altares, estatuas y templos en su honor (2. 4. 2); que los egipcios son el pueblo más piadoso del mundo (2.37.1); que Heracles participaba del panteón egipcio y que los griegos adoptaron el nombre del héroe merced a los egipcios (2.43.1-2); que el origen de los dioses griegos procede de Egipto (2.49-52). Entre otros detalles de fuste, resulta verosímil que, desde una óptica sincrónica (e indudablemente diacrónica), las noticias de Heródoto resultaran difícilmente compatibles con un concepto de la religiosidad privativamente griego y, en todo caso, alertaran sobre una característica propia del historiador: su propensión a describir las prácticas religiosas con el mismo afán costumbrista que exhibe en otros aspectos destacables de la Historia. Por añadidura, es patente la tendencia de Heródoto a racionalizar los mitos, de modo que presenta la versión (conocida en el Ática ${ }^{167}$ ) sobre la presencia de Helena en Egipto (2.113-115). Insiste Heródoto en que esa versión la conocía también Homero pero que este la obvió por un criterio de efectismo narrativo. $Y$ es que si Helena hubiera estado en Troya, el rey Príamo la habría entregado a los griegos para esquivar una suerte peor (2. 116-117). Finalmente no debe soslayarse que, si aceptamos la tradición más acreditada, la exposición herodotea fue divulgada en Atenas mediante alocución pública, de suerte que cualquier ciudadano ateniense -letrado o iletrado- pudo acceder al relato del historiador.

${ }^{165}$ Cf. Sánchez Mañas 2015: 311. Por lo demás, como indica la autora (309 n. 425), es “el único episodio oracular de la obra que recoge una respuesta emanada exclusivamente de la sede de Zeus en Dodona”.

${ }^{166}$ En tal sentido, cf. Ramón Palerm 2013b.

167 Sobre esta versión, alternativa de la convencionalmente presente en el imaginario colectivo, ahondan los testimonios de Eurípides (en su Helena) y Aristófanes (en Las Tesmoforiantes). Al respecto, cf. Ramón Palerm 2013c: 729-731. 


\subsection{Tucídides}

Como viene siendo convencionalmente reconocido, la obra historiográfica de Tucídides constituye -al margen de esquemas tipológicos inherentes al conjunto de la historiografía griega- un avance descomunal en la técnica compositiva del relato histórico, con el propósito (que revela paladinamente la sección de la Arqueología [1. 2-19]) de examinar los testimonios del pasado merced a los indicios razonables, de carácter científico-técnico, para la valoración correcta del fenómeno histórico ${ }^{168}$. Siendo así en el ámbito de la formalización historiográfica, el estudioso se enfrenta a un compromiso de envergadura por cuanto concierne a los aspectos (ir)religiosos que laten en la Historia de la Guerra del Peloponeso. En seguimiento de una prolongada tradición sobre los estudios tucidídeos, ya Hornblower se pronunciaba sobre la renuencia de Tucídides por espigar en cuestiones de índole religiosa ("religious silences" es la expresión concreta del especialista) ${ }^{169}$. Se trata efectivamente de la apreciación más significativa que impacta a la comunidad científica: la ausencia de dioses en la exposición de los acontecimientos; la reticencia deliberada en el manejo de los esquemas religiosos; el escepticismo o desdén respecto de adivinos e intérpretes de oráculos; la gelidez en las referencias, siquiera alusivas, a hechos de factura religiosa. En efecto, Tucídides exhibe la elocuencia de su disciplinado silencio cual metodología operativa. En suma, el lector arrostra con plenitud la vaciedad de númenes en la obra del historiador; y alberga incidentalmente la impresión de hallarse ante un notario o instructor forense del cuerpo sociopolítico. La crítica histórico-filológica cuenta, en los últimos años, con ciertas contribuciones incisivas en la dirección que mencionamos, contribuciones que subrayan (con matices sensiblemente graduales en sus valoraciones) la característica primordial y antedicha del historiador ateniense. Debemos probablemente a Furley el estudio global más penetrante sobre el modus operandi de Tucídides en el tratamiento de las cuestiones (ir)religiosas ${ }^{170}$. Con buena lógica, Furley declina manifestarse sobre la credulidad o incredulidad de Tucídides en materia religiosa y opta por investigar las empresas que acometen los personajes interesados, llevados a menudo -estos sí- por razonamientos o posiciones donde las potencias divinas parecieran desempeñar un papel preponderante ${ }^{171}$. De esta guisa, el autor incluye a Tucídides en el inventario de los intelectuales y fisicistas del siglo $\mathrm{V}$

168 En general, cf. Ramón Palerm 1996b; Schrader 1997; Caballero López 2010 (especialmente 109-116).

${ }^{169}$ Hornblower 1992: 170. El artículo presenta un título harto relevante: "The Religious Dimension to the Peloponnesian War, or, What Thucydides Does Not Tell Us”.

${ }^{170}$ Furley 2006.

${ }^{171}$ Lo subrayamos al modo de Newton (2010: 119): “In Thucydides' History the divine exists only in the minds of men". 
a.C. cuyo escepticismo sobre el ámbito de actuación divina en la intervención humana (que afecta igualmente a las admoniciones oraculares) se muestra ponderadamente esbozado. Así las cosas, Furley prefiere ajustarse a las implicaciones psicológicas de las creencias religiosas en el quehacer basculante de los responsables político-militares ${ }^{172}$. Al respecto, varios episodios merecen la atención particular del estudioso. Valga inicialmente la intervención de Pericles (2. 64. 2), donde el estadista defiende su acción de gobierno -en plena crisis de peste que asola la ciudad-cuando insta a sus conciudadanos a sobrellevar los asuntos divinos con resignación y las asechanzas de los

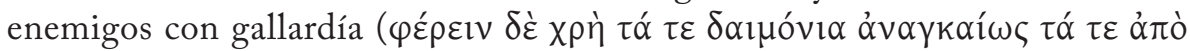
$\left.\tau \tilde{\omega} v \pi \circ \lambda \varepsilon \mu i^{\prime} \omega v \alpha \dot{\alpha} v \delta \rho \varepsilon i ́ \omega \varsigma\right)^{173}$. El segundo episodio de importancia se inscribe en el célebre Diálogo de los melios (concretamente 5. 104-105), con pasajes en los que contrasta la apelación ingenua de los representantes melios a la divinidad (la cual intercedería en favor de los melios habida cuenta la causa justa que ellos propugnan) y la respuesta sofístico-retórica de la embajada ateniense, con el argumento (cuya cercanía con las posiciones agnósticas al modo de Protágoras juzga probable Furley) de que el conocimiento de los dioses escapa a la inteligencia humana. El tercer y significativo episodio abarca los preparativos y el desenlace de la frustrada expedición a Sicilia -la cual ofrece connotaciones ostentosamente trágicas, añadimos- que culmina con el desastre colosal de la flota ateniense y la muerte de sus estrategos, Nicias y Demóstenes. Sin duda hay factores extraordinariamente relevantes que, como demuestra Furley, conectan con la psicología religiosa de sucesos y personajes. He ahí, por ejemplo, el vandalismo callejero que constituyó la 'Mutilación de los Hermes' y la celebración sacrílega de la 'Profanación de los Misterios', actos de impiedad que fueron convenientemente explotados por los sectores políticos anti-Alcibiades ${ }^{174}$. Así las cosas, será Nicias quien encabece las operaciones, un Nicias reconocidamente tildado por el historiador de sujeto timorato, supersticioso, proclive a las manifestaciones de prodigios y a los signos adivinatorios: es ilustrativo el pasaje de 7.50.4, cuando Nicias aborta una maniobra naval por mor de un eclipse lunar; o la arenga que consta en 7. 77, donde Nicias manifiesta su fe inveterada en los dioses. Por contra, el siracusano Hermócrates desdeña una festividad en honor de Heracles para idear una estratagema de éxito contra la flota ateniense (7.73) ${ }^{175}$. A nuestro parecer, hechos de esta naturaleza parecen desprender una explicación

${ }^{172}$ Se trata probablemente de la sección más brillantemente analizada en la aportación de Furley (2006: 424-238).

${ }^{173}$ Resulta verosímil, en nuestra opinión, que Pericles efectúe aquí una utilización pro

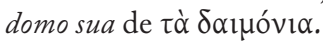

${ }^{174}$ Cf. Leão 2012, donde el autor analiza apropiadamente las circunstancias mencionadas.

${ }^{175}$ Furley 2006: 435-438. 
plausible: quienes, como Nicias, anteponen las eventuales revelaciones divinas o predicciones mánticas al planteamiento humanamente cabal de la estrategia operativa se ven indefectiblemente abocados al fracaso en sus proyectos.

Como era de esperar, la deriva que adoptan los acontecimientos sume a la ciudadanía ateniense en un enojo desesperanzado sobre los intérpretes de oráculos, los adivinos y cuantos vaticinaron la toma de Sicilia, contingencia que

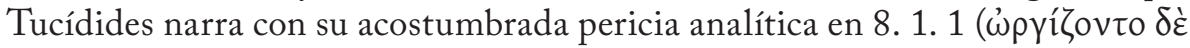

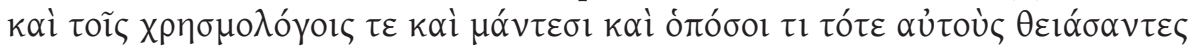

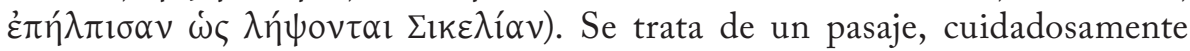
estudiado por la crítica, el cual parece ofrecer el declive de la población en su creencia de los poderes numinosos ${ }^{176}$. Sin embargo, Flower discute esta interpretación y opina que Tucídides es personalmente responsable de un enfoque desafortunado en el manejo de los hechos ${ }^{177}$. El estudioso concede la existencia de cambios incidentales para la consideración del esquema religioso en la Atenas finisecular, pero niega la existencia de una crisis profunda en las prácticas y creencias religiosas. Es más, juzga que Tucídides obvia intencionadamente información sobre aspectos religiosos de importancia y que exhibe una tendencia indisimulada a menoscabar la influencia de la actividad religiosa como factor determinante en los asuntos humanos. Por cierto que la censura de Flower a la perspectiva metodológica de nuestro historiador no redunda sino en probar quod erat demonstrandum: que la opacidad de mutismo relativa a la arquitectura religiosa es característica singular en el quehacer del historiador ateniense. Adicionalmente, Lévy ha impulsado un eficaz análisis léxico a terminología de índole prioritariamente socio-jurídica ${ }^{178}$ : se trata de

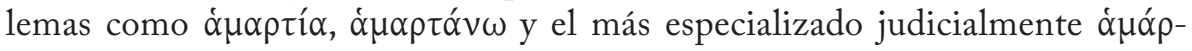
$\tau \eta \mu \alpha$ que, en otros géneros y autores de la época (recuérdese lo advertido acerca particularmente de Antifonte), cobran una dimensión retórico-(ir) religiosa. Pues bien, un análisis exhaustivo de las concurrencias inherentes a la raíz ó $\mu \alpha \rho \tau-$ en la Historia de la Guerra del Peloponeso evidencia que Tucídides imprime al vocabulario concerniente una denotación ajustada al nivel del pensamiento, de la acción y del ámbito ético-jurídico. En síntesis, todo parece enfatizar esa reluctancia pertinaz del historiador para acoger la incidencia del factor religioso en su modelo explicativo.

Al cabo, mediante esta selección sumaria solo aspiramos a presentar las vías de orientación actuales, entre la comunidad científica, para el estudio de los autores literarios cuya incidencia en las vicisitudes (ir)religiosas de la Atenas

\footnotetext{
${ }^{176}$ Cf. Furley 2006: 437-438. Asimismo, cf. Zimm 2010.

${ }^{177}$ Flower 2009.

${ }^{178}$ Lévy 2008.
} 
Clásica se revela notable. Como puede apreciarse, los análisis interpretativos más recientes vienen primando con pulcritud exponencial modelos de naturaleza léxico-semántica que, a nuestro criterio, pueden contribuir a una valoración inductiva y comparada de los aspectos más distinguidos sobre el tema. Pues bien, creemos que en esta línea directriz deben asentarse y ahondar las tendencias inmediatas de la investigación. 